\title{
Atmospheric methane control mechanisms during the early Holocene
}

\author{
Ji-Woong Yang ${ }^{1}$, Jinho Ahn ${ }^{1}$, Edward J. Brook ${ }^{2}$, and Yeongjun Ryu ${ }^{1}$ \\ ${ }^{1}$ School of Earth and Environmental Sciences, Seoul National University, Seoul 08826, Republic of Korea \\ ${ }^{2}$ College of Earth, Ocean, and Atmospheric Sciences, Oregon State University, Corvallis, OR 97331, USA \\ Correspondence to: Jinho Ahn (jinhoahn@snu.ac.kr)
}

Received: 1 July 2016 - Discussion started: 13 July 2016

Revised: 5 August 2017 - Accepted: 8 August 2017 - Published: 22 September 2017

\begin{abstract}
Understanding processes controlling the atmospheric methane $\left(\mathrm{CH}_{4}\right)$ mixing ratio is crucial to predict and mitigate future climate changes in this gas. Despite recent detailed studies of the last $\sim 1000$ to 2000 years, the mechanisms that control atmospheric $\mathrm{CH}_{4}$ still remain unclear, partly because the late Holocene $\mathrm{CH}_{4}$ budget may be comprised of both natural and anthropogenic emissions. In contrast, the early Holocene was a period when human influence was substantially smaller, allowing us to elucidate more clearly the natural controls under interglacial conditions more clearly. Here we present new high-resolution $\mathrm{CH}_{4}$ records from Siple Dome, Antarctica, covering from 11.6 to 7.7 thousands of years before $1950 \mathrm{AD}(\mathrm{ka})$. We observe four local $\mathrm{CH}_{4}$ minima on a roughly 1000 -year spacing, which correspond to cool periods in Greenland. We hypothesize that the cooling in Greenland forced the Intertropical Convergence Zone (ITCZ) to migrate southward, reducing rainfall in northern tropical wetlands. The inter-polar difference (IPD) of $\mathrm{CH}_{4}$ shows a gradual increase from the onset of the Holocene to $\sim 9.5 \mathrm{ka}$, which implies growth of boreal source strength following the climate warming in the northern extratropics during that period.
\end{abstract}

\section{Introduction}

Methane $\left(\mathrm{CH}_{4}\right)$ is a potent greenhouse gas whose atmospheric mixing ratio has increased more than 2.5 times since the Industrial Revolution (Dlugokencky et al., 2009). Although lower in abundance compared to carbon dioxide $\left(\mathrm{CO}_{2}\right), \mathrm{CH}_{4}$ has $\sim 28$ times higher global warming potential (GWP) on a 100-year timescale and even higher GWP on shorter timescales due to its short atmospheric lifetime (IPCC, 2013). Hence understanding the controls on atmospheric $\mathrm{CH}_{4}$ is important to predict and mitigate future climate and environmental changes.

Naturally, $\mathrm{CH}_{4}$ is mainly produced from microbial decomposition by methanogens in anaerobic environments, such as waterlogged soil, wetlands, or sediments of lakes and rivers. Even though a part of $\mathrm{CH}_{4}$ is oxidized, and can be emitted in the form of $\mathrm{CO}_{2}$, a considerable amount of $\mathrm{CH}_{4}$ is still released into the atmosphere through vascular plants, diffusion and ebullition processes (e.g. Joabsson and Christensen, 2001). Other, more minor sources include geological $\mathrm{CH}_{4}$ released from mud volcanoes and gas seepages through faults (e.g. Etiope et al., 2008, and references therein), pyrogenic sources such as wildfire and biomass burning (Andreae and Merlet, 2001; Ferretti et al., 2005; Hao and Ward, 1993), and microbial digestion by wild animals and termites (e.g. Sanderson, 1996). The $\mathrm{CH}_{4}$ flux from the ocean to the atmosphere is considered as too small to create a significant change in global budget compared to the other sources (e.g. Rhee et al., 2009). The major sink of atmospheric $\mathrm{CH}_{4}$ is photochemical reactions (oxidation) with the hydroxyl radical $(\mathrm{OH})$, which is mainly controlled by atmospheric temperature, humidity, and the mixing ratio of $\mathrm{CH}_{4}$ itself and non-methane volatile organic compound (NMVOC) (e.g. Levine et al., 2011, and references therein). Air temperature affects humidity thereby limiting the production of $\mathrm{OH}$. Oxidation of both NMVOCs and $\mathrm{CH}_{4}$ compete for $\mathrm{OH}$, that is, an increase in NMVOC emission reduces the available $\mathrm{OH}$, and increases the atmospheric lifetime of $\mathrm{CH}_{4}$ (Valdes et al., 2005). Further, since the $\mathrm{OH}$ is produced by photo-dissociation reaction, the $\mathrm{CH}_{4}$ sink strength 
is affected by light availability and tropospheric ozone (e.g. Levy II, 1971). However, recent model studies suggested that $\mathrm{CH}_{4}$ changes between glacial and interglacial conditions were driven mostly by source changes, rather than sink changes (Weber et al., 2010; Levine et al., 2011).

Polar firn and ice are the unique archives that preserves the ancient atmosphere for the research of fossil air older than the 20th century. Palaeoatmospheric $\mathrm{CH}_{4}$ levels have been reconstructed for the last $800 \mathrm{kyr}$ from Antarctic and Greenland ice cores (Loulergue et al., 2008). Given the relatively long lifetime in troposphere (11.2 \pm 1.3 years at present, e.g. Prather et al., 2012) compared to atmospheric mixing time, ice core $\mathrm{CH}_{4}$ records represent well-mixed global signatures. The $800 \mathrm{kyr}$ record shows that past $\mathrm{CH}_{4}$ change generally followed glacial-interglacial cycles, with low concentrations during glacial periods and high concentrations in interglacials, as well as the shorter orbital cycles of obliquity and precession (e.g. Spahni et al., 2005; Loulergue et al., 2008). Those earlier studies suggested that the changes in climate and hydrology in the tropics induced by orbital forcing controlled $\mathrm{CH}_{4}$ emissions. The resemblance between water stable isotope records from Greenland ice cores, a proxy for Greenland temperature change, and global $\mathrm{CH}_{4}$ mixing ratios on millennial timescales is also well known. This implies that local temperature change around Greenland is linked to the major $\mathrm{CH}_{4}$ sources in low latitudes (e.g. Brook et al., 1996; Chappellaz et al., 1993; Huber et al., 2006; EPICA Community Members, 2006; Grachev et al., 2007, 2009).

Intensive precipitation changes in the low-latitude summer monsoon regions, caused by insolation changes (e.g. Asian monsoon) have been suggested as an important $\mathrm{CH}_{4}$ control during the glacial period (e.g. Chappellaz et al., 1990). From time series analysis of past $\mathrm{CH}_{4}$ records, Guo et al. (2012) found that the tropical monsoon circulation is a primary control of relatively shorter (millennial) timescale variability, while long-term (multimillennial to orbital scale) variations are dominated by solar insolation changes. It has been found that tropical monsoon activity is closely related to orbitalscale $\mathrm{CH}_{4}$ change (e.g. Brook et al., 1996; Chappellaz et al., 1990), especially Asian monsoon (e.g. Loulergue et al., 2008) and South American monsoon (e.g. Cruz et al., 2005). However, no direct correlation between $\mathrm{CH}_{4}$ and tropical monsoon signals has been reported for the early Holocene, although positive relationships between Greenland climate and tropical monsoon intensity (e.g. Chiang et al., 2008), as well as between Greenland climate and $\mathrm{CH}_{4}$ (e.g. Spahni et al., 2005; Wang et al., 2005; Mitchell et al., 2011) have been reported.

The relationship between the latitudinal shift of the ITCZ and $\mathrm{CH}_{4}$ emissions varies with timescales. Landais et al. (2010) and Guo et al. (2012) suggested that ITCZ migration is not a dominant control of glacial-interglacial $\mathrm{CH}_{4}$ cycle because long-term $\mathrm{CH}_{4}$ trend does not follow the precessional insolation change in the Northern Hemisphere (NH) well. Modelling studies found the southward shift of the ITCZ coincides with reduced $\mathrm{CH}_{4}$ in Last Glacial Maximum (LGM) and Heinrich stadial (HS) events, even though changes in wetland area and surface hydrology were limited (Weber et al., 2010; Hopcroft et al., 2011). These authors instead suggested that changes in temperature and/or plant productivity affected $\mathrm{CH}_{4}$ production during those events. ITCZ migration does appear to be related to millennial- or submillennial-scale $\mathrm{CH}_{4}$ change, however. Brook et al. (2000) found that submillennial $\mathrm{CH}_{4}$ minima during the last deglaciation correspond with reduced precipitation recorded in Cariaco Basin sediment data, which indicates southward displacement of ITCZ (Hughen et al., 1996). This hypothesis is supported by spectral analysis of $\mathrm{CH}_{4}$ during the past $800 \mathrm{kyr}$ record that found that ITCZ change becomes an important driver of millennial-scale $\mathrm{CH}_{4}$ change (Tzedakis et al., 2009; Guo et al., 2012).

For the Holocene, high-resolution $\mathrm{CH}_{4}$ records from Law Dome and West Antarctic Ice Sheet (WAIS) Divide ice cores in Antarctica show characteristic variability on multidecadal to centennial timescale during the late Holocene (MacFarling-Meure et al., 2006; Mitchell et al., 2011). The high-resolution records have been compared with various temperature and precipitation proxies, but previous work found no strong correlations that explain the observed decadal- to centennial scale variabilities. This may be because the late Holocene $\mathrm{CH}_{4}$ budget was comprised of both natural and anthropogenic terms, making it difficult to distinguish between them. Mitchell et al. (2011) pointed out that some of the abrupt $\mathrm{CH}_{4}$ decreases could have had anthropogenic causes. Later, Mitchell et al. (2013) made simultaneous measurement of Antarctic (WAIS Divide) and Greenland (Greenland Ice Sheet Project 2; GISP2) ice cores to derive an IPD record, and extended their high-resolution records back to $\sim 4$ ka. They used an eight-box atmospheric methane model (EBAMM) and anthropogenic and natural emission scenarios to investigate $\mathrm{CH}_{4}$ control factors. Their results showed that the late Holocene $\mathrm{CH}_{4}$ evolution can be explained by a combination of natural and anthropogenic emissions. In principle, stable isotope ratios of $\mathrm{CH}_{4}$ help us to distinguish the types of sources - biogenic, pyrogenic, and geologic. Sowers (2010) reconstructed the $\mathrm{CH}_{4}$ mixing ratio and stable isotopic composition $\left({ }^{13} \mathrm{C}-\mathrm{CH}_{4}\right.$ and $\left.\delta \mathrm{D}-\mathrm{CH}_{4}\right)$ throughout the entire Holocene. He suggested several possible control factors, such as boreal wetlands and thermokarst lakes, changing $\mathrm{C}_{3} / \mathrm{C}_{4}$ plant ratio of $\mathrm{CH}_{4}$-emitting ecosystems, and changing composition of methanogenic communities. Previous studies have shown reduction of pyrogenic emission and increased agricultural emission during the last millennium (Ferretti et al., 2005; Mischler et al., 2009). In later work using $\delta^{13} \mathrm{C}-\mathrm{CH}_{4}$ records from North Greenland Eemian Ice Drilling (NEEM) ice core, Sapart et al. (2012) found that the centennial-scale variations during the last two millennia were caused by changes in pyrogenic and biogenic emissions. Ruddiman et al. (2011) and Sapart et al. (2012) estimated $\mathrm{CH}_{4}$ emission change due to anthropogenic land 
Gas age (kyr BP, individual age scale)

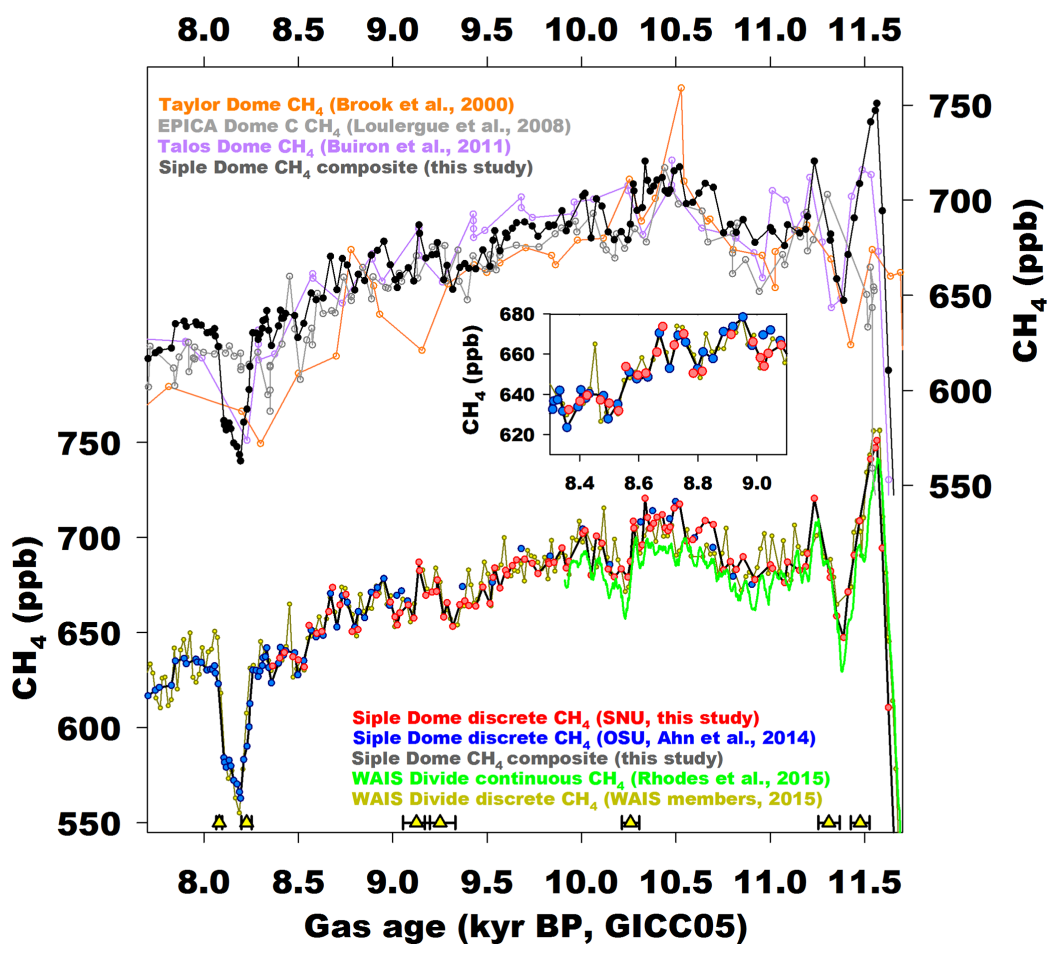

Figure 1. Atmospheric $\mathrm{CH}_{4}$ concentration reconstructions during the early Holocene. Top: new high-resolution Siple Dome composite (black; this study and Ahn et al., 2014) compared with previous records from Taylor Dome (orange; Brook et al., 2000), EPICA Dome C (grey; Loulergue et al., 2008), and Talos Dome (purple; Buiron et al., 2011). Bottom: Siple Dome $\mathrm{CH}_{4}$ records measured at OSU (blue; Ahn et al., 2014) and SNU (red; this study). Siple Dome composite (black line) is plotted with WAIS Divide discrete (dark yellow; WAIS Divide project members, 2015) and continuous measurement records (green; Rhodes et al., 2015). Inset: enlarged plot showing overlapped interval between OSU and SNU Siple Dome data.

use changes, which shows a good agreement with the trends from ice core measurement. There is no high-resolution reconstruction of past population and land use area, and consequently large uncertainties of $\mathrm{CH}_{4}$ emission from land use change impede identification of any shorter-scale changes.

The early Holocene is a suitable period to study natural $\mathrm{CH}_{4}$ controls under Holocene interglacial climate condition. Since there was only negligible human population and relevant $\mathrm{CH}_{4}$-emitting anthropogenic activities (e.g. Goldewijk et al., 2010; Kaplan et al., 2011) during this time, the early Holocene $\mathrm{CH}_{4}$ changes must have occurred mostly due to natural causes. Understanding natural controls could contribute to better constraints on human-induced $\mathrm{CH}_{4}$ changes. However, high-resolution studies that cover the entire early Holocene have not been carried out extensively so far, except for studies of the prominent cooling event at $8.2 \mathrm{ka}$ (Spahni et al., 2003; Kobashi et al., 2007; Ahn et al., 2014). Although Rhodes et al. (2015) reported a very high-resolution record from WAIS Divide ice core that extends from the last glacial period to the earliest Holocene ( $\sim 9.8 \mathrm{ka})$, the authors do not deal with the early Holocene $\mathrm{CH}_{4}$ variability. Earlier studies mainly focused on long-term change, attributing the major control to low-latitude hydrology based on regional climate records that show wetter climate in tropics during the early Holocene (Blunier et al., 1995; Brook et al., 2000; Chappellaz et al., 1993, 1997). Therefore, in this study we present a new high-resolution $\mathrm{CH}_{4}$ record from the early Holocene and investigate natural control mechanisms under interglacial condition. It should be noted that environmental boundary conditions of the early Holocene were not identical to those of the late Holocene. Global sea level rose throughout the early Holocene while remnant ice sheets in North America disappeared.

\section{Materials and methods}

In this study we used ice samples from the Siple Dome deep ice core (SDMA) drilled from 1997 to 1999 on the Siple Coast, West Antarctica $\left(81.65^{\circ} \mathrm{S}, 148.81^{\circ} \mathrm{W} ; 621 \mathrm{~m}\right.$ elevation) (Taylor et al., 2004). The SDMA samples were collected and cut at National Ice Core Laboratory (NICL, Denver, Colorado, USA) from January to February of 2013. The brittle zone of SDMA ice starts below $400 \mathrm{~m}$ and continues to the bottom of the core at $1004 \mathrm{~m}$ (Gow and Meese, 2007) 
Table 1. Summary of results of replicate analysis from eight depth intervals. The rightmost two columns show the difference between the means of the first and the second measurements. The depth difference between the first and second replicate samples is $10 \mathrm{~cm}$.

\begin{tabular}{|c|c|c|c|c|c|c|c|c|c|}
\hline \multirow{2}{*}{$\begin{array}{l}\text { Depth } \\
\text { (m) }\end{array}$} & \multicolumn{4}{|c|}{ First measurement } & \multicolumn{4}{|c|}{ Second measurement } & \multirow{2}{*}{$\begin{array}{r}\text { Difference } \\
\text { in means } \\
1 \mathrm{st}-2 \mathrm{nd}\end{array}$} \\
\hline & $\begin{array}{r}\text { Dup.1 } \\
\text { (ppb) }\end{array}$ & $\begin{array}{r}\text { Dup.2 } \\
\text { (ppb) }\end{array}$ & $\begin{array}{r}\text { Mean } \pm 1 \sigma \\
(\mathrm{ppb})\end{array}$ & $\begin{array}{r}\text { Date } \\
(\mathrm{dd} / \mathrm{mm} / \mathrm{yyyy})\end{array}$ & $\begin{array}{r}\text { Dup.1 } \\
\text { (ppb) }\end{array}$ & $\begin{array}{r}\text { Dup.2 } \\
\text { (ppb) }\end{array}$ & $\begin{array}{r}\text { Mean } \pm 1 \sigma \\
(\mathrm{ppb})\end{array}$ & $\begin{array}{r}\text { Date } \\
(\mathrm{dd} / \mathrm{mm} / \text { yyyy })\end{array}$ & \\
\hline 523.150 & 634.8 & 634.7 & $634.7 \pm 0.1$ & 27-01-2014 & 637.5 & 634.3 & $635.9 \pm 1.6$ & $24-02-2014$ & -1.2 \\
\hline 530.950 & 669.0 & 665.8 & $667.4 \pm 1.6$ & 03-02-2014 & 669.4 & 670.7 & $670.0 \pm 0.7$ & 24-02-2014 & -2.6 \\
\hline 558.295 & 682.5 & 678.2 & $680.3 \pm 2.2$ & $14-03-2014$ & 687.5 & 678.3 & $682.9 \pm 4.6$ & 02-04-2014 & -2.6 \\
\hline 559.850 & 689.8 & 680.3 & $685.0 \pm 4.7$ & 03-02-2014 & 683.8 & 690.0 & $686.9 \pm 3.1$ & 26-03-2014 & -1.9 \\
\hline 561.150 & 687.8 & 689.2 & $688.5 \pm 0.7$ & $14-03-2014$ & 684.0 & 690.4 & $687.2 \pm 3.2$ & 02-04-2014 & 1.3 \\
\hline 562.407 & 687.2 & 685.5 & $686.4 \pm 0.8$ & 26-03-2014 & 689.4 & 686.4 & $687.9 \pm 1.5$ & 02-04-2014 & -1.5 \\
\hline 575.913 & 679.2 & 679.2 & $679.2 \pm 0.0$ & $07-02-2014$ & 686.7 & 678.9 & $682.8 \pm 3.9$ & 28-03-2014 & -3.6 \\
\hline 578.150 & 675.6 & 685.1 & $680.4 \pm 4.7$ & $04-02-2014$ & 676.0 & 680.7 & $678.3 \pm 2.4$ & $24-04-2014$ & 2.0 \\
\hline
\end{tabular}

and samples from this region are more likely to be fractured. Hence, the samples were carefully collected from unbroken subsections during sample preparation at NICL. The samples were packed in insulated foam boxes with numerous eutectic gels, and shipped to South Korea via expedited airfreight. Temperature loggers showed the temperatures were maintained below $-25^{\circ} \mathrm{C}$. The boxes were picked up directly just after custom clearance at the airport and then the ice samples were stored in a walk-in freezer at Seoul National University (SNU, Seoul, South Korea) that was maintained below $-20^{\circ} \mathrm{C}$. We measured 295 individual ice samples from 156 depth intervals from 518.87 to $718.83 \mathrm{~m}$, covering from 8.36 to $20.25 \mathrm{ka}$ after synchronizing to the Greenland Ice Core Chronology 2005 (GICC05; Rasmussen et al., 2006), of which 256 ice samples from 120 depth intervals from 518.87 to $623.38 \mathrm{~m}$ are used in this study. All samples were duplicated, so that our final $\mathrm{CH}_{4}$ data were presented by averaging the results of duplicate analysis from the same depth. The analytical uncertainty of our data set is estimated by the uncertainty of individual ice measurement divided by square root of 2 (see below). We rejected data that show difference between duplicate measurements larger than $10 \mathrm{ppb}$, and nine data points were rejected in the studied period. The results of SNU measurement (111 points) are plotted in Fig. 1. The 16 samples from 8 depths were used for reproducibility check on different days (Table 1). The air occluded in ice was extracted by a melting and refreeze process under vacuum. Ice samples were prepared in a walkin freezer in the morning of each experiment day, the outermost $>2 \mathrm{~mm}$ was trimmed off to eliminate potential contamination by ambient air during the storage. The samples were then moved to the laboratory and placed in glass sample containers. The sample flasks were custom-made glass flasks welded to stainless steel flanges, and attached to the vacuum line with copper gaskets. The sample flasks were partially submerged in a chilled ethanol bath while being attached to the vacuum line. Flasks were evacuated for at least $40 \mathrm{~min}$, then the ice samples were melted by submerging the sample flasks in a warm water bath. Melting was usually completed within $30 \mathrm{~min}$. The sample flasks were then submerged in the cold ethanol bath chilled to around $-82^{\circ}$ for more than an hour to refreeze. During refreezing, we carried out daily calibration of the gas chromatograph system, normally taking $\sim 90 \mathrm{~min}$. The ethanol temperature normally rose to $-55^{\circ} \mathrm{C}$ just after submerging the flasks, and recovered to $-65^{\circ} \mathrm{C}$ before expansion of the air in the flasks. The extracted air in the headspace was expanded into the evacuated vacuum line and sample loop of a gas chromatograph (GC) equipped with a flame ionization detector (FID) to measure $\mathrm{CH}_{4}$ mixing ratio. After detecting the $\mathrm{CH}_{4}$ peak in the GC chromatogram (retention time of $\sim 1.6 \mathrm{~min}$ ), the vacuum line and sample loop is evacuated again prior to the next injection. The GC linearity was tested by a series of inter-tank calibration using four working standard air cylinders (395.5, 721.3, 895.0, and $1384.9 \mathrm{ppb} \mathrm{CH}_{4}$ on NOAA04 scale; Dlugokencky et al., 2005). A daily GC calibration curve was determined by measurements of a working standard having the closest $\mathrm{CH}_{4}$ mixing ratio of expected value from the samples; in this study, we used the $721.3 \mathrm{ppb} \mathrm{CH}_{4}$ standard for samples of the early Holocene. We calibrated with a standard air six times before and after sample measurements. The detailed configuration of the vacuum line and GC is described in another paper (Yang et al., 2017).

Different solubilities of each air component cause preferential dissolution during melting procedure. As the solubility of $\mathrm{CH}_{4}$ is higher than the other major components of air nitrogen $\left(\mathrm{N}_{2}\right)$, oxygen $\left(\mathrm{O}_{2}\right)$, argon $(\mathrm{Ar})-$ the $\mathrm{CH}_{4}$ mole fraction of the extracted air is lower than originally enclosed air (solubility effect). The $\mathrm{CH}_{4}$ mole fraction of air enclosed in ice sample is estimated from residual gas fraction and the $\mathrm{CH}_{4}$ mixing ratio in air remaining in refrozen meltwater (retrapped air). Residual gas fraction is a measure of how much 
air is retrapped during refreeze, which is defined as the ratio of amount (pressure) of air extracted from the second gas extraction to the first extraction. The second gas extraction was carried out using leftover refrozen meltwater samples after the first extraction finished. Mean residual gas fraction is $1.05 \pm 0.13 \%(1 \sigma, n=60)$ for SDMA ice samples and $0.38 \pm 0.08 \%(1 \sigma, n=40)$ for bubble-free ice. The test with ice samples from Styx Glacier, Antarctica, revealed that $\mathrm{CH}_{4}$ mixing ratio in retrapped air is enriched 3.1 times $(n=12)$ for glacial ice and 3.0 times $(n=7)$ for bubble-free ice. Then the solubility effect is corrected by using a simple mass balance calculation.

Daily systematic offset correction was applied to account for the daily varying system condition. To do this, we measured four bubble-free ice samples every day with SDMA ice samples. The experimental procedures for the bubble-free ice were identical to the SDMA ice. After the sample flasks are evacuated, standard air is injected into the flasks containing bubble-free ice, so that it returns similar air pressure to the typical size of SDMA ice when the extracted air inside the bubble-free ice flasks is expanded into the sample loop. The solubility correction for the bubble-free ice was done by the same formula as SDMA ice samples, but using different residual gas fraction. After correction for solubility effect, the daily systematic offset is calculated from the difference between $\mathrm{CH}_{4}$ mixing ratio of the injected standard air and results from the four flasks containing bubble-free ice. The systematic offset ranges from 5 to $15 \mathrm{ppb}$ during the SDMA measurement period. A daily offset is subtracted from the ice samples corrected for gas solubility effect. This is one of the major differences with OSU wet extraction system, where the systematic offset is interpolated from the results of blank tests carried out over several days (Mitchell et al., 2011).

The bubble-free ice was made by chilling the degassed ultrapure water (resistivity $>18.2 \mathrm{M} \Omega \mathrm{cm}$ at $25^{\circ} \mathrm{C}$ ) slowly from the bottom in a closed stainless steel chamber. From gas extraction test using our bubble-free ice without injecting standard air, we observed no significant pressure increase at the pressure gauge with a detection limit of 0.01 Torr (corresponding to less than $0.03 \%$ of sample air pressure in the extraction line) after melting-refreezing the bubble-free ice. Mass-dependent (gravitational) fractionation within the firn (Craig et al., 1988; Schwander, 1989) was corrected by using the nitrogen isotope ratio $\left(\delta^{15} \mathrm{~N}\right)$ of atmospheric $\mathrm{N}_{2}$ occluded in bubbles. Siple Dome $\delta^{15} \mathrm{~N}$ records show a mean enrichment of $0.23 \pm 0.01 \%$ o during the early Holocene (Severinghaus et al., 2009) and result in a slight decrease in $\mathrm{CH}_{4}$ by $1.97 \pm 0.15 \mathrm{ppb}$, which we applied to all of our measurements.

Here we consider two types of uncertainty sources: uncertainty in (1) estimating daily systematic offset and (2) other causes. The former indicates uncertainty of the daily systematic offset $(e 1)$. As the daily systematic offset is calculated from the mean of the four flasks with bubble-free ice and standard air, scattering of the bubble-free ice samples can induce uncertainty in the systematic offset correction. The daily $e 1$ is estimated with standard error of the mean (SEM, $n=4$ ), because the daily systematic offset is calculated from the mean of the four bubble-free ice samples. The average of daily $e 1$ is $1.9 \mathrm{ppb}$. The latter (e2) includes uncertainty due to solubility correction and inhomogeneous distribution of $\mathrm{CH}_{4}$. Given that our solubility correction uses the mean value of residual gas fraction and the ratio at which $\mathrm{CH}_{4}$ enriches in retrapped air, different solubility effect and/or inhomogeneous $\mathrm{CH}_{4}$ distribution in individual ice causes an offset between adjacent duplicate ice samples analysed on the same day. As the duplicates from same depths were measured on the same day, we estimated the $e 2$ with pooled standard deviation (PSD) between duplicate measurements from entire depths, which yields $3.3 \mathrm{ppb}$. Taking the $e 1$ and $e 2$ into account together, the final uncertainty of individual measurement is given as $3.8 \mathrm{ppb}$ by error propagation. The uncertainty for the mean of duplicate results is obtained by dividing the individual uncertainty by the square root of 2 , yielding $2.7 \mathrm{ppb}$. Further details on the correction method is found in our paper in preparation (Yang et al., 2017).

We made additional measurements using adjacent samples (depth difference of $10 \mathrm{~cm}$ ) at eight randomly selected depth intervals to examine reproducibility and long-term stability of our system. The second measurements of duplicates were performed 8 to 80 days after the first analysis. Table 1 displays quadruplicate results at each depth. The PSD between the mean of duplicate analyses of the first and second measurements on different days yields $1.1 \mathrm{ppb}$. The good agreement between duplicate means indicates good reproducibility of our system. The PSD of the quadruplicate measurements is $3.0 \mathrm{ppb}$, which is similar to the PSD of duplicate samples for the entire data set (3.3 ppb).

To check reliability of the record we compared our data set with previous SDMA measurements at Oregon State University (OSU) for the 8.4-9.1 ka period, when the two records overlap. The OSU $\mathrm{CH}_{4}$ record was measured with a temporal resolution of 8 years with precision of $2.8 \mathrm{ppb}$ (Mitchell et al., 2011; Ahn et al., 2014). The average offset between the two data sets is $0.1 \mathrm{ppb}$, which lies within the analytical uncertainty range of the data sets. Therefore, we created a composite record by using the OSU data for 499.49$537.20 \mathrm{~m}$ interval (7.6 to $9.0 \mathrm{ka}$ ) because the mean temporal resolution of OSU data ( $\sim 22$ years) is lower than that of the SNU data ( $\sim 37$ years) during this period (Fig. 1). Our new SDMA $\mathrm{CH}_{4}$ composite data have mean temporal resolution of $\sim 26$ years. The WAIS Divide continuous $\mathrm{CH}_{4}$ records show much higher resolution ( $\sim 2$ years), but does not cover the entire early Holocene period (Rhodes et al., 2015). 


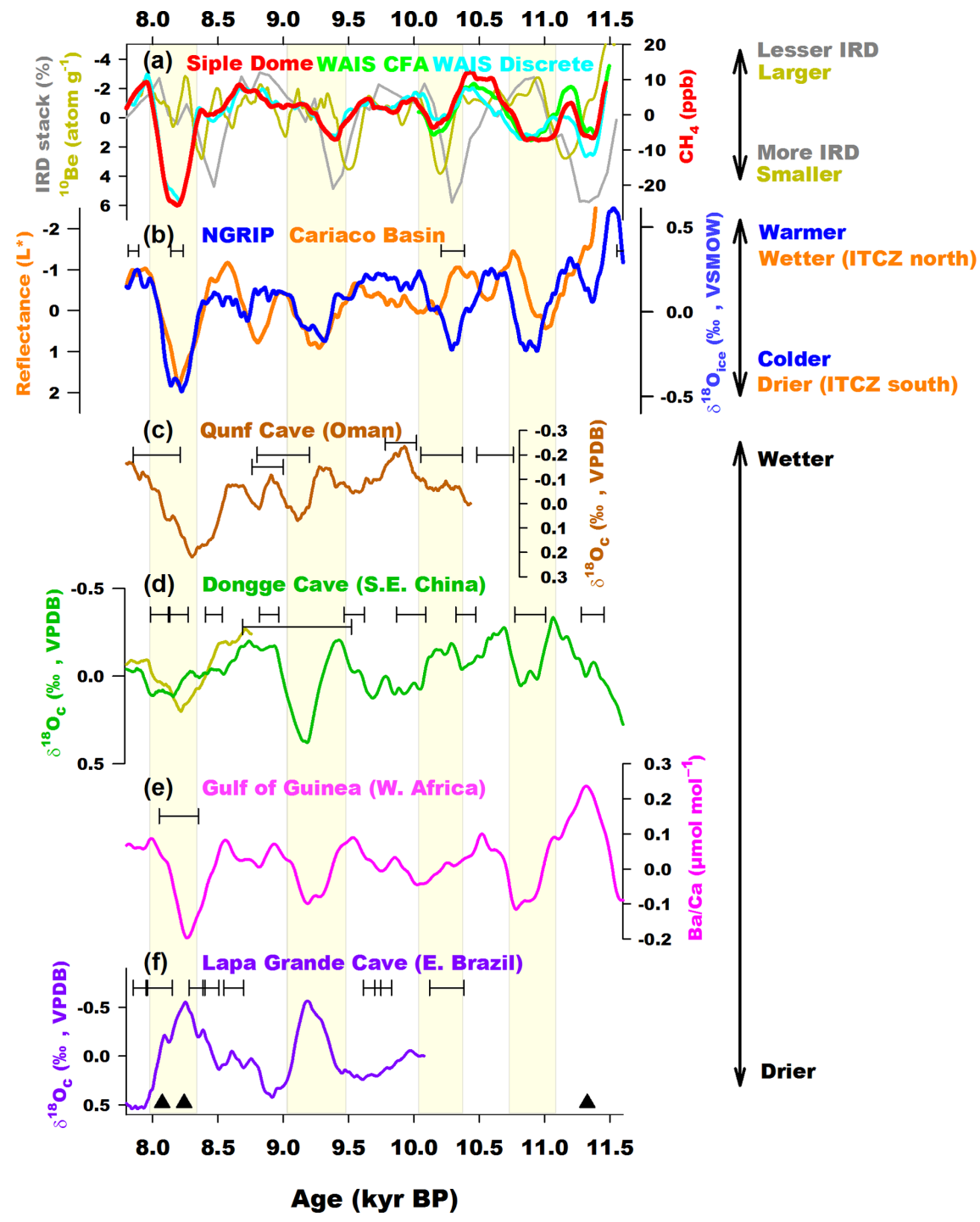

Figure 2. Millennial-scale climate variability. All proxies presented here were smoothed by 250 -year running average and detrended by highpass filter with 1/1800-year window. (a) Siple Dome $\mathrm{CH}_{4}$ (red, this study), Greenland ${ }^{10} \mathrm{Be}$ (dark yellow; Finkel and Nishizumii, 1997), North Atlantic IRD stack (grey, Bond et al., 2001). Also shown are WAIS Divide $\mathrm{CH}_{4}$ data by discrete (cyan, denoted "WAIS Discrete"; WAIS Divide project members, 2015) and continuous (yellow green, denoted "WAIS CFA"; Rhodes et al., 2015) technique. (b) NGRIP stable water isotope ratio (blue; Rasmussen et al., 2006) and Cariaco Basin reflectance (orange, Deplazes et al., 2013). (c) Qunf Cave speleothem oxygen isotope (Fleitmann et al., 2007). (d) Dongge Cave speleothem oxygen isotope (green: Dykoski et al., 2005; dark yellow: Wang et al., 2005). (e) Gulf of Guinea planktonic Ba / Ca ratio (Weldeab et al., 2007). (f) Lapa Grande Cave speleothem oxygen isotope (purple; Strikis et al., 2011). Black solid triangles are age tie points used to adjust Siple Dome and WAIS Divide $\mathrm{CH}_{4}$ data to GICC05 scale.

\section{Result and discussion}

\subsection{Millennial-scale variability}

We carried out spectral analysis of the SDMA composite record using the REDFIT program (Schulze and Mudelsee, 2002). Moderate (over $90 \%$ significance level) spectral power was found at 1340-, 401-, 309-, and 96-year periods. Given the $\sim 42$ years of gas age distribution of SDMA (Ahn et al., 2014), it would not be reliable to study centennial-scale variability. Therefore, we smoothed the data by a 250 -year running average to remove centennial- to multicentennialscale components and then detrended by a high-pass filter with a cut off period of 1800 years to isolate millennial-scale variability. For comparison, the same processing scheme was applied to WAIS Divide time series and we observed that Siple Dome and WAIS Divide $\mathrm{CH}_{4}$ anomalies share similar millennial-scale variability, confirming the reliability of both our data and observed millennial-scale changes (Fig. 2).

The high-pass-filtered $\mathrm{CH}_{4}$ time series demonstrates millennial-scale minima at $\sim 8.2,9.3,10.2$ and $10.9 \mathrm{ka}$, 


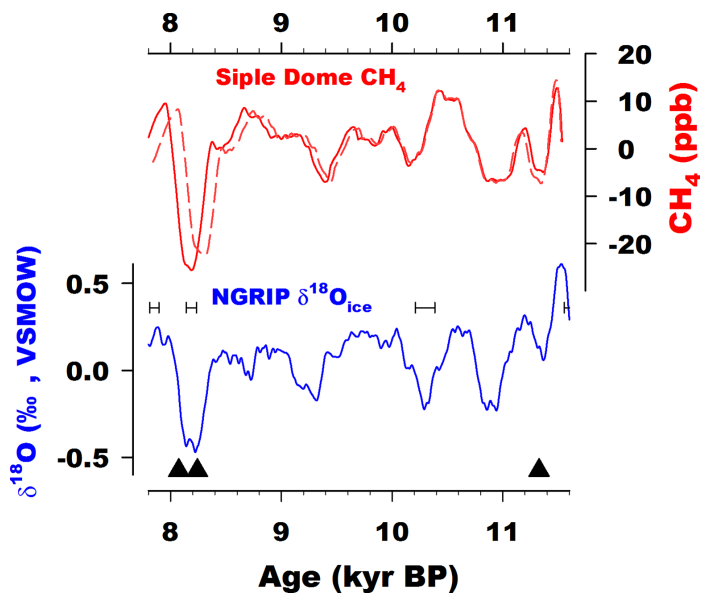

Figure 3. Top: comparison between Siple Dome $\mathrm{CH}_{4}$ anomalies plotted with gas age adjusted to GICC05 (red, solid) and previous gas age (red, dashed; Brook et al., 2005). Bottom: NGRIP $\delta^{18} \mathrm{O}$ anomaly in GICC05 scale. The horizontal error bars denote the age uncertainty of GICC05 chronology (Rasmussen et al., 2006), and the black triangles are age tie points used to adjusting the Siple Dome age scale to GICC05 scale.

which occurred with nearly 1000 -year spacing. The REDFIT results for 7.6 to $11.2 \mathrm{ka}$ interval that excludes the Preboreal Oscillation (PBO) shows moderate (80\% significance level) powers at $\sim 731$ and 430 (860)-year periods. Each minimum is accompanied by depletion of water stable isotope ratio $\left(\delta^{18} \mathrm{O}_{\text {ice }}\right)$ from North Greenland Ice Core Project (NGRIP) ice core, which implies climate cooling in Greenland. A close relationship between $\mathrm{CH}_{4}$ and Greenland $\delta^{18} \mathrm{O}_{\text {ice }}$ has been previously reported in glacial-interglacial cycles and Dansgaard-Oeschger (DO) events during the last glacial period (e.g. Brook et al., 1996, 2000; Blunier and Brook, 2001; Chappellaz et al., 1993, 2013; EPICA Community Members, 2006). However, it has not been confirmed for interglacial climate conditions during the Holocene. Mitchell et al. (2011) found no significant correlation with Greenland climate at multidecadal scale during the late pre-industrial Holocene (LPIH), possibly because the LPIH $\mathrm{CH}_{4}$ budget is also affected substantially by anthropogenic emissions (e.g. Ferretti et al., 2005; Mischler et al., 2009; Mitchell et al., 2013; Sapart et al., 2012). In contrast, we observe a significant positive correlation $(r=0.57, p=0.06)$ between the millennial-scale change of Siple Dome $\mathrm{CH}_{4}$ and NGRIP $\delta^{18} \mathrm{O}_{\text {ice }}$ during the early Holocene. The correlation coefficient between the smoothed and filtered time series of SDMA $\mathrm{CH}_{4}$ (before synchronization to GICC05) and NGRIP $\delta^{18} \mathrm{O}_{\text {ice }}$ was calculated for 7.8-11.5 ka by interpolating to the original ages of SDMA $\mathrm{CH}_{4}$ composite, with a reduced degree of freedom.

The gas chronology of SDMA was developed based on $\mathrm{CH}_{4}$ and $\delta^{18} \mathrm{O}$ of air $\left(\delta^{18} \mathrm{O}_{\mathrm{atm}}\right)$ correlation (Severinghaus et al., 2009). In this study, we improved the chronology by

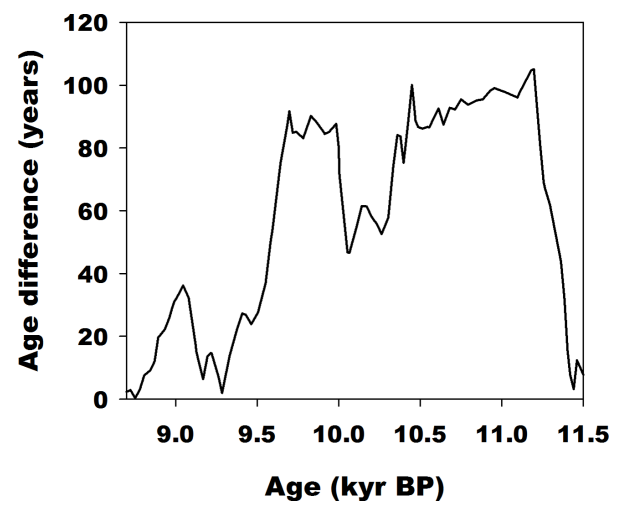

Figure 4. Age difference between the new gas age scale adjusted to GICC05 by Monte Carlo matching with NEEM discrete $\mathrm{CH}_{4}$ (Chappellaz et al., 2013) and the original gas age based on $\mathrm{CH}_{4}$ and $\delta^{18} \mathrm{O}_{\text {atm }}$ correlation (Severinghaus et al., 2009).

synchronization of the previous chronology to GICC05 age scale by setting three age tie points with stable water isotope $\left(\delta^{18} \mathrm{O}\right)$ record from the NGRIP ice cores during the abrupt climate change events of PBO and the $8.2 \mathrm{ka}$ event, given that both events have been proved to be synchronous with $\mathrm{CH}_{4}$ change (Kobashi et al., 2007, 2008). Ages between tie points were inferred by linear interpolation of the age offset of nearest tie points, which range from -114 to 28 years. After synchronizing to the GICC05 scale, the correlation coefficient between SDMA $\mathrm{CH}_{4}$ composite and the NGRIP $\delta^{18} \mathrm{O}_{\text {ice }}$ increases to $r=0.74(p<0.01)$ This implies that the natural $\mathrm{CH}_{4}$ budget is closely connected with Greenland climate on millennial timescales, even though this conclusion is less robust as there are no age tie points between the $8.2 \mathrm{ka}$ episode and PBO (Fig. 3). The positive correlation implies that the natural $\mathrm{CH}_{4}$ budget is connected with Greenland climate on millennial timescales.

The uncertainty of the modified chronology was examined by comparing with a tentative age scale determined by $\mathrm{CH}_{4}$ correlation with NEEM $\mathrm{CH}_{4}$ discrete measurement data. $\mathrm{NEEM} \mathrm{CH}_{4}$ data follow the GICC05modelext-NEEM1 scale (Rasmussen et al., 2013). The detailed method for $\mathrm{CH}_{4}$ correlation is described in Sect. 3.2. The age difference between the two chronologies is plotted in Fig. 4, showing the maximum age difference of 105 years. In addition, we include the maximum layer counting uncertainty of 99 years (Rasmussen et al., 2006) and delta age uncertainty of 30 years (Rasmussen et al., 2013) during the early Holocene. Therefore, error propagation of the above three errors indicate that the maximum error of SDMA gas age used in this study is $\sim 147$ years.

According to atmospheric modelling studies, abrupt cooling in the North Atlantic regions can alter atmospheric circulation and cause southward migration of the mean latitudinal position of the ITCZ (e.g. Chiang and Bitz, 2005; Broccoli et al., 2006; Cvijanovic and Chiang, 2013). Climate proxies 
demonstrate the climatic teleconnection between the northern North Atlantic and low-latitude regions. The sediment reflectance record from Cariaco Basin shows increased rainfall and humidity - which is due to southward displacement of ITCZ - corresponding to the 8.2, 9.3, and $10.9 \mathrm{ka}$ abrupt cooling event, as revealed in previous studies for the different time periods (Peterson et al., 2000; Haug et al., 2001; Fleitmann et al., 2007; Deplazes et al., 2013). The southward displacement of the ITCZ leads to further weakening of Asian and Indian summer monsoons and probably reduces $\mathrm{CH}_{4}$ emission from northern tropical wetlands. The ${ }^{18} \mathrm{O}$ enrichment in speleothems from Dongge Cave (China), Qunf Cave (Oman), and Hoti Cave (Oman, not shown; Neff et al., 2001) occurred at similar timing with abrupt cooling in Greenland at 8.2, 9.3, and $10.9 \mathrm{ka}$, which indicates the reduction of monsoonal rainfall in northern tropical wetlands. The speleothem records from Chinese and Oman caves seem to lag by $\sim 100-200$ years after the $\mathrm{CH}_{4}$ change at $\sim 9.3 \mathrm{ka}$, but this lies within chronological uncertainties of $\sim 200$ 400 years at around $\sim 9.0 \mathrm{ka}$ (Dykoski et al., 2005; Fleitmann et al., 2007). Moreover, sediment $\mathrm{Ba} / \mathrm{Ca}$ ratio from Gulf of Guinea demonstrates concurrent decrease in West African monsoon (Weldeab et al., 2007). In contrast, an inverse relationship is observed from the eastern Brazilian speleothem data (Lapa Grande Cave; Strikis et al., 2011) that suggest an increase in precipitation at the time of abrupt $\mathrm{CH}_{4}$ decreases. Rhodes et al. (2015) pointed out that strong southward migration of the ITCZ could induce an abrupt $\mathrm{CH}_{4}$ increase from the Southern Hemisphere (SH) during the HS 1, 2, 4, and 5 events. Sperlich et al. (2015) also suggested that a sharp $\mathrm{CH}_{4}$ peak at Greenland Interstadial $21.2(\sim 85 \mathrm{ka})$ was caused by emission from Asian and Amazon wetlands. However, considering the orbital parameters that indicate maximum summer insolation in $\mathrm{NH}$ and minimum in $\mathrm{SH}$ during the early Holocene, it can be inferred that the contribution of SH wetland emission was relatively weak and overcompensated by reduction of $\mathrm{NH}$ emission.

The possibility that the observed $\mathrm{CH}_{4}$ minima were caused by reduction of northern extratropical sources is not supported by previous modelling studies. Zürcher et al. (2013) found that abrupt cooling in Greenland and northern high latitudes by large freshwater input to the North Atlantic causes boreal peatland $\mathrm{CH}_{4}$ emission to decrease substantially, which can explain $\sim 23 \%$ of abrupt $\mathrm{CH}_{4}$ decrease ( $\sim 80 \mathrm{ppb})$ during the $8.2 \mathrm{ka}$ event. Given the meltwater pulses during the early Holocene before the $8.2 \mathrm{ka}$ event were probably much weaker (Teller and Leverington, 2004) than that corresponding to the $8.2 \mathrm{ka}$ event, we suggest that boreal emission change is not the major cause of the $\mathrm{CH}_{4}$ local minima.

Previously, Björck et al. (2001) found that climate cooling in the northern Atlantic and Santa Barbara Basin occurred associated with a change in solar forcing at $\sim 10.3 \mathrm{ka}$. However, the proxy data in Fig. 2 show no clear indication of southward migration of the ITCZ and changes in Asian,

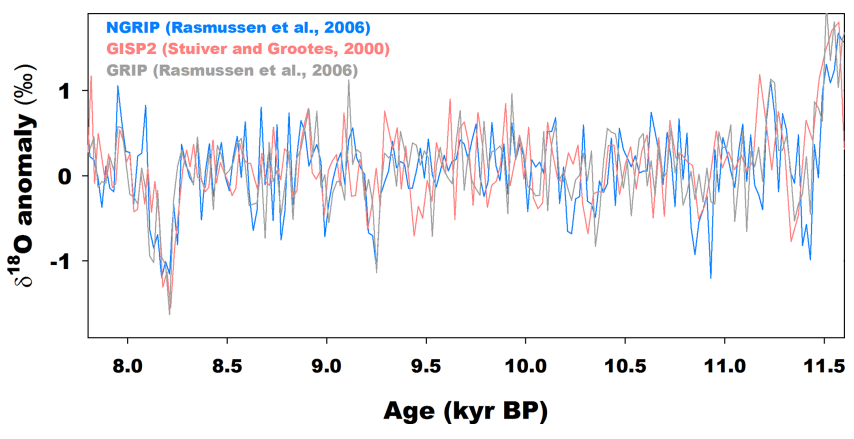

Figure 5. Comparison of Greenland oxygen isotope ratios from NGRIP (blue, Rasmussen et al., 2006), GRIP (grey, Rasmussen et al., 2006) and GISP2 (red, Stuiver and Grootes, 2000). All time series were high-pass-filtered with 1/1800-year window. Note that the cooling amplitude at $10.3 \mathrm{ka}$ is smaller than 8.2 and $9.3 \mathrm{ka}$ events in NGRIP records, but this is not clear in GRIP and GISP2 ice cores.

Indian, African, and South American summer monsoon intensity associated with the $\sim 10.2 \mathrm{ka}$ cooling and $\mathrm{CH}_{4}$ decrease (Fig. 2b-f). Furthermore, speleothem $\delta^{18} \mathrm{O}$ records from Mawmluh Cave (not shown) show no weakening of the Indian monsoon (Berkelhammer et al., 2012), and there was no distinct change in $\Delta \varepsilon_{\text {LAND }}$, a proxy of global terrestrial respiratory fractionation of atmospheric $\mathrm{O}_{2}$ at this time, which is affected by low-latitude surface hydrology (Severinghaus et al., 2009). This evidence suggests that precipitation and surface hydrology in the northern tropics may have not changed significantly around the $10.2 \mathrm{ka}$. Instead, there are two small decreases at $\sim 9.9$ and $\sim 10.6$ ka as shown in the Dongge Cave deposit record (Fig. 2d), but it is difficult to tell, given dating uncertainties, whether these events correlate with the $10.2 \mathrm{ka}$ cooling. Although there appears to have been no strong change in low-latitude hydrology at $10.2 \mathrm{ka}$, the amplitude of $\mathrm{CH}_{4}$ decrease at $10.2 \mathrm{ka}$ is of similar order to the other millennial events. Given that no clear reduction of the Asian, Indian, and African monsoon intensity is observed, it is possible that the $\mathrm{CH}_{4}$ decrease at $10.2 \mathrm{ka}$ was controlled by other processes, outside of the northern tropics.

Previous studies have suggested an important role of solar forcing during the Holocene (e.g. Björck et al., 2001; Bond et al., 1997, 2001). Bond et al. (1997) reported that four large ice-rafted debris (IRD) drifts occurred at $\sim 8.1$, 9.4, 10.3 and $11.1 \mathrm{ka}$ caused by surface cooling of North Atlantic Ocean. They found that the ocean surface cooling and the IRD events are closely related to cooling over Greenland. Figure 2 shows that each IRD event (maxima in hematite-stained grain) occurred concurrently with minima of the NGRIP $\delta^{18} \mathrm{O}_{\text {ice }}$ record within age uncertainty. We postulate that the Greenland cooling leads to a southward shift of the ITCZ which in turn changes wetland $\mathrm{CH}_{4}$ emission in low latitudes. Bond et al. (2001) found that IRD maxima during the Holocene coincide with solar activity min- 
ima and suggested that solar forcing could affect the climate change around the North Atlantic Ocean (and Greenland), through amplification by changes in sea ice and/or deep water formation. A close interplay between solar activity and monsoon intensity has been observed in previous studies using the Chinese and Oman speleothem records during the Holocene (Neff et al., 2001; Wang et al., 2005; Gupta et al., 2005), even on multidecadal timescales (Agnihotri et al., 2002). However, the forcing mechanism of solar activity on the North Atlantic and global climate is not well understood. Jiang et al. (2015) found positive correlations between North Atlantic SST and solar forcing inferred from palaeo-proxies $\left({ }^{14} \mathrm{C}\right.$ and $\left.{ }^{10} \mathrm{Be}\right)$ for the last 4000 years, although the correlation disappears during the mid- and early Holocene. They hypothesized that climate sensitivity to solar forcing is high for cooler climates. The above evidence suggests that the early Holocene $\mathrm{CH}_{4}$ minima may be linked to anomalies in solar activity, but future study is needed to make this conclusive.

Meanwhile, a shift to an El Niño-like SST state was suggested as another mechanism that changes tropical rainfall patterns (Marchitto et al., 2010). According to modern atmospheric observations, El Niño conditions lead to drying conditions in low-latitude wetlands in Africa, Asia, and the Americas (e.g. Dai and Wigley, 2000; Lyon and Barnston, 2005; Hodson et al., 2011), which reduces tropical $\mathrm{CH}_{4}$ emissions. Thus, we could speculate that both the ITCZ migration and El Niño-like SST change affected the tropical surface hydrology and $\mathrm{CH}_{4}$ emission. According to Holocene ENSO activity reconstructions by Moy et al. (2002), no ENSO event was recorded during the early Holocene until around $7 \mathrm{ka}$, except for weak ENSO events during 10.4-10.1 ka, where we observe a $\mathrm{CH}_{4}$ drop apparently unrelated to monsoon proxies. Mitchell et al. (2011) observed a significant positive correlation between $\mathrm{CH}_{4}$ and Pacific decadal oscillation (PDO) variability during the late Holocene. It has been reported that PDO modulates the wet/dry impact of ENSO depending on phase relationship between ENSO and PDO (e.g. Wang et al., 2014, and references therein). A Holocene PDO reconstruction from sediment grain size analysis by Kirby et al. (2010) shows PDOrelated drying intervals in North America during 9.5-9.1, 8.9-8.6, and 8.3-7.8 ka, which overlap the $\mathrm{CH}_{4}$ minima at 8.2 and $9.3 \mathrm{ka}$ present in this study.

\subsection{Inter-polar difference of $\mathrm{CH}_{4}$ during the early Holocene}

We calculated the inter-polar difference (IPD) of $\mathrm{CH}_{4}$ to trace the latitudinal source distribution change during the early Holocene. The currently available high-resolution $\mathrm{CH}_{4}$ records covering the early Holocene are SDMA discrete (this study), WAIS Divide discrete (WAIS Divide project members, 2015), WAIS Divide continuous (Rhodes et al., 2015), NEEM discrete (Chappellaz et al., 2013), and NEEM continuous data (Chappellaz et al., 2013). Among the Antarc- tic records, we consider WAIS continuous records most reliable from the $\sim 9.9$ to $11.5 \mathrm{ka}$ interval. For the rest of the studied period, SDMA discrete records are better constrained than WAIS discrete data, because SDMA records have better analytical precision, and comparison with OSU measurements reveals a minimal offset for the early Holocene interval. Before IPD calculation, WAIS continuous data were calibrated to SDMA data, given that discrete measurements generally have better accuracy than continuous ones. Regarding the Greenland side, we use NEEM discrete records because not only there are discrepancies between continuous and discrete data in some intervals but also because NEEM discrete records were measured by similar wet extraction technique at OSU (Chappellaz et al., 2013).

Precise synchronization is crucial for direct comparison between data sets which have high-frequency variations. For synchronizing between Antarctic (Siple Dome and WAIS Divide continuous) and NEEM records, the NEEM $\mathrm{CH}_{4}$ record ( $\sim 11$-year resolution on average) is chosen as reference. Synchronization was done in two steps. First, we made an initial synchronization between the Antarctic and NEEM data by setting match points at the midpoint of abrupt $\mathrm{CH}_{4}$ change, then we linearly interpolated the age offset of each match point for the rest of the data points. Then we applied a Monte Carlo simulation to find a maximum correlation. Both data sets were resampled every 30 years, and each point was randomly perturbed (assuming a normal distribution with $1 \sigma$ of 30 years). By doing so 1000 different time series were created, and the set having a maximum correlation with NEEM data was chosen. Criteria for "best fit" is correlation coefficient of 0.8 with the NEEM original age scale, so that a maximum correlation less than 0.8 was discarded. This procedure was repeated to make 20 sets of maximum correlation time series, and the mean ages of 20 replicate simulations were set to synchronized age scale. The uncertainty range of IPD was calculated from synchronization uncertainty and $\mathrm{CH}_{4}$ data uncertainty. To estimate synchronization uncertainty, we created 20 IPDs from the 20 sets of maximum correlation time series, and the standard deviation of the 20 records was taken as synchronization uncertainty for each of the data points. The $\mathrm{CH}_{4}$ data uncertainty was estimated with the stated uncertainty of each data set (4.3 ppb for NEEM discrete/2.7 ppb for SDMA/1.5 ppb for WAIS continuous, $1 \sigma$ ). To check the sensitivity of the uncertainties, we carried out Monte Carlo simulations. We produced 1000 different sets of IPD, which vary randomly with Gaussian propagation in their ages and $\mathrm{CH}_{4}$ concentration uncertainties. Each IPD was annually interpolated and smoothed by a $1 / 1000 \mathrm{yr}^{-1}$ low-pass filter. The cut-off frequency of 1000 years was chosen to examine multicentennial- to millennial-scale change, because the IPD calculation is very sensitive to high-frequency variability of $\mathrm{CH}_{4}$ records from both poles. To report $95 \%$ confidence interval, we multiplied the standard deviation by 1.96 and enveloped the IPD. 


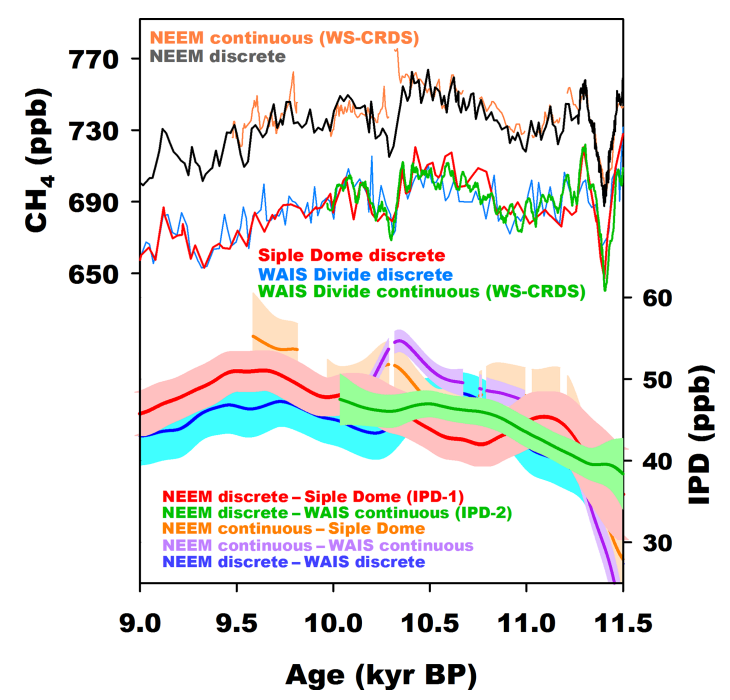

Figure 6. $\mathrm{CH}_{4}$ inter-polar difference (IPD) and high-latitude $\mathrm{CH}_{4}$ sources. Top: high-resolution $\mathrm{CH}_{4}$ discrete measurements from NEEM discrete (black; Chappellaz et al., 2013), NEEM continuous (orange; Chappellaz et al., 2013), WAIS Divide discrete (light blue; WAIS Divide project members, 2015), WAIS Divide continuous (green; Rhodes et al., 2015), and Siple Dome (red, this study) ice core records. Bottom: 1000-year low-pass-filtered IPD reconstructions by using various pairs of Greenland and Antarctic records, in which the IPD-1 and IPD-2 are shown in red and green, respectively. The shaded area indicates $95 \%$ significance interval.

Figure 6 displays the IPDs calculated from various pairs of data set with $95 \%$ significant interval. The two IPD records derived from the most reliable data sets are plotted in red (NEEM discrete - Siple Dome, IPD-1 hereafter) and green (NEEM discrete - WAIS continuous, IPD-2 hereafter). Both IPD-1 and IPD-2 show a long-term increase from 11.5 to $9.9 \mathrm{ka}$, which indicates that boreal source contribution was enhanced. However, IPD-1 shows a sharper increase during the PBO followed by decrease until $\sim 10.7 \mathrm{ka}$, and in the latter case both IPDs differ beyond the $95 \%$ envelope (from 10.4 to $10.8 \mathrm{ka}$ ). Although these differences are significant, and are probably due to small errors in the timescale and absolute concentration differences, for example due to uncertainties in blank corrections or solubility corrections, or core quality, they do not affect our basic interpretation of the trends. Instead, we combined the two IPDs to resolve this. Given that IPD-2 is better constrained than IPD-1, we use the IPD-2 curve from the 9.9 to $11.5 \mathrm{ka}$ interval and IPD-1 for the rest of the studied period (Fig. 7). The combined IPD shows $\sim 13 \mathrm{ppb}$ increase from 11.5 to $9.5 \mathrm{ka}$. It displays a similar trend with the $\mathrm{NH}$ extratropical $\left(30-90^{\circ} \mathrm{N}\right)$ temperature reconstruction (Marcott et al., 2013) and the modelled $\mathrm{CH}_{4}$ emission from boreal thermokarst lakes (Walter Anthony et al., 2014), indicating that NH extratropical source strength increased during this period.

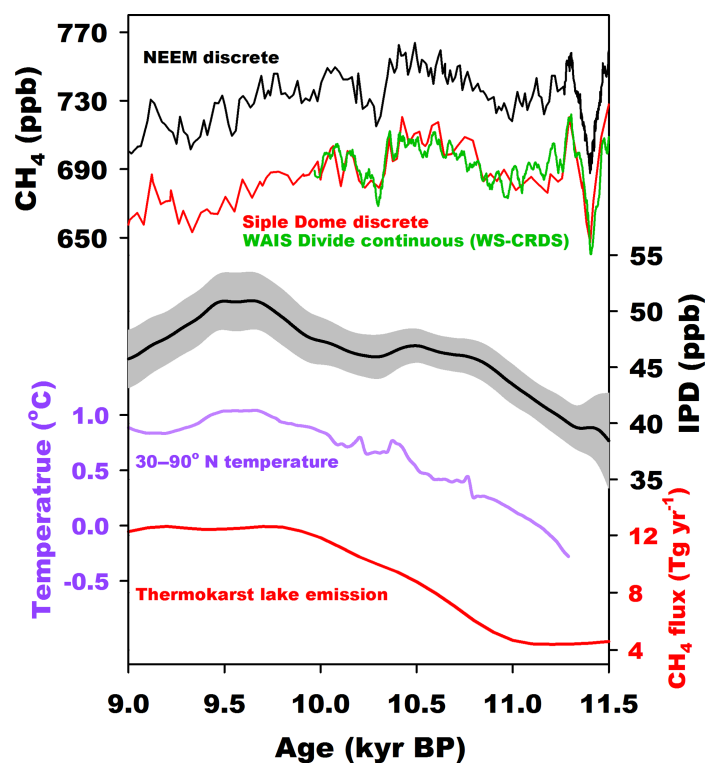

Figure 7. $\mathrm{CH}_{4}$ inter-polar difference (IPD) and high-latitude $\mathrm{CH}_{4}$ sources. Top: high-resolution $\mathrm{CH}_{4}$ discrete measurements from NEEM discrete (black; Chappellaz et al., 2013), WAIS Divide continuous (green; Rhodes et al., 2015), and Siple Dome (red, this study) ice core records. Middle: 1000-year low-pass-filtered combined IPD with $95 \%$ significance interval (shaded). Bottom: previous estimates are marked in green and orange (Brook et al., 2000; Chappellaz et al., 2013). Proxy-based temperature reconstruction for $30-90^{\circ} \mathrm{N}$ (purple; Marcott et al., 2013). $\mathrm{CH}_{4}$ flux estimate from Siberian and Alaskan thermokarst lakes (red; Walter Anthony et al., 2014).

To quantify the source strength of low- and high-latitude sources, we employed a simple three-box $\mathrm{CH}_{4}$ source distribution model as used in previous studies (Chappellaz et al., 1997; Brook et al., 2000). Briefly, the model contains three boxes: northern extratropical latitude $\left(30-90^{\circ} \mathrm{N}, \mathrm{N}\right.$ box $)$, tropical $\left(30^{\circ} \mathrm{S}-30^{\circ} \mathrm{N}, \mathrm{T}\right.$ box $)$, and southern extratropical latitude boxes $\left(30-90^{\circ} \mathrm{S}, \mathrm{S}\right.$ box). $\mathrm{CH}_{4}$ mixing ratios in the three boxes (in $\mathrm{Tg}$ box ${ }^{-1}$ ) were determined from $\mathrm{CH}_{4}$ mixing ratio of Antarctica and Greenland. The mean $\mathrm{CH}_{4}$ mole fraction of the $\mathrm{N}$ box $\left(30-90^{\circ} \mathrm{N}\right)$ is not identical to that of Greenland ice core record, given the latitudinal $\mathrm{CH}_{4}$ distribution (e.g. Fung et al., 1991). To derive the N-box $\mathrm{CH}_{4}$, we followed the assumption of Chappellaz et al. (1997), where the authors assumed that the difference between Greenland and the mean N-box $\mathrm{CH}_{4}$ is $7 \%$ of IPD. Hence here the N-box $\mathrm{CH}_{4}$ is calculated by subtracting $7 \%$ of IPD from the Greenland mixing ratio. The T-box mixing ratio is inferred by assuming that the S-box emission is constant of $15 \mathrm{Tg} \mathrm{yr}^{-1}$ (Fung et al., 1991). Emission from each box $\left(\mathrm{Tg} \mathrm{yr}^{-1}\right)$ is then estimated by using the mixing ratios of the boxes, the lifetime of $\mathrm{CH}_{4}$ in each box, and transport times between the boxes. Following Chappellaz et al. (1997), we assume lifetime of 18.7, 8.1, and 26.8 years in N, T, and S box, respectively, and transport time of 9 months. The modelled emission changes are plot- 
Table 2. Results of the three-box source distribution model from the combined IPD showing emissions of tropical (green, T) and boreal $(\mathrm{red}, \mathrm{N})$ boxes and boreal source fraction $(\mathrm{N} /(\mathrm{T}+\mathrm{N}+\mathrm{S}))$ at specific time slices. Also shown are previous estimates for comparison. Errors denote $95 \%$ confidence interval. The uncertainty for the $9.5-11.5$ ka period is the average of $95 \%$ confidence interval of the low-pass-filtered reconstruction of each box emission.

\begin{tabular}{l|rr|r}
\hline Ref. & N box & T box & $\begin{array}{r}\text { Boreal source fraction } \\
\mathrm{N} /(\mathrm{N}+\mathrm{T}+\mathrm{S})\end{array}$ \\
\hline (ka) & $\left(\mathrm{Tg} \mathrm{yr}^{-1}\right)$ & $(\%)$ \\
\hline Brook et al. (2000) (9.5-11.5 ka) & $64 \pm 5$ & $123 \pm 8$ & $32 \pm 3$ \\
Chappellaz et al. (1997) (9.5-11.5 ka) & $66 \pm 8$ & $120 \pm 9$ & $33 \pm 3$ \\
This study (9.5-11.5 ka) & $67 \pm 3$ & $118 \pm 5$ & $33 \pm 2$ \\
This study (11.5 ka) & $60 \pm 7$ & $118 \pm 12$ & $31 \pm 4$ \\
This study (9.5 ka) & $71 \pm 3$ & $109 \pm 5$ & $36 \pm 2$ \\
This study (9.0 ka) & $66 \pm 4$ & $112 \pm 7$ & $34 \pm 2$ \\
\hline
\end{tabular}

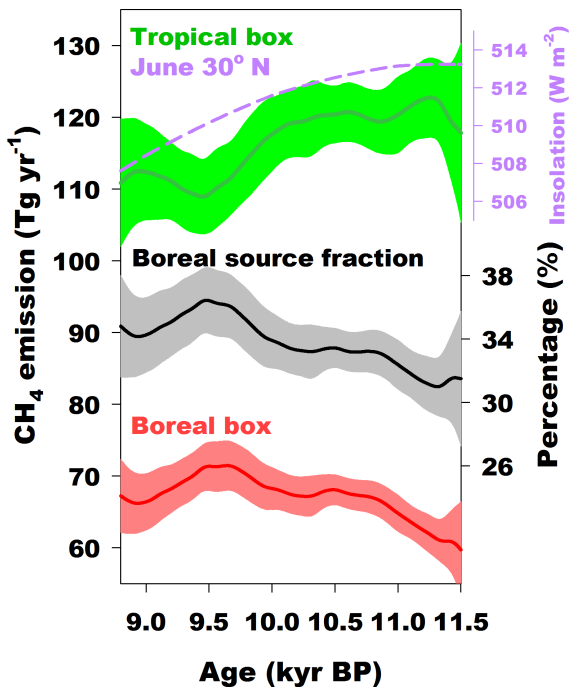

Figure 8. Three-box source distribution model results of tropical (green) and boreal (red) boxes. Black line shows the boreal to total source fraction (see text). Purple dashed line plotted with tropical emission is summer insolation in $30^{\circ} \mathrm{N}$ (Berger and Loutre, 1991).

ted in Fig. 8. The model results reveal that tropical sources decrease (accounting for the largest portion in $\mathrm{CH}_{4}$ budget), while NH extratropical emissions increase. The T-box emission is reduced from $\sim 118$ to $\sim 109 \mathrm{Tg} \mathrm{yr}^{-1}$, and the N-box source strength increases from $\sim 60$ to $\sim 71 \mathrm{Tg} \mathrm{yr}^{-1}$ during the 11.5-9.5 ka interval (Fig. 8). The long-term decrease in tropical emission follows the $\mathrm{NH}$ summer insolation change. This covariation may reflect the insolation-driven changes in emissions on a multimillennial timescale (e.g. Loulergue et al., 2008; Guo et al., 2012). Also plotted in Fig. 8 is the boreal source fraction, defined as ratio of $\mathrm{N}$-box emission to total source emissions, showing 5\% increase (from 31.5 to $36.5 \%$ ) during the same interval. The box model results at 9.0, 9.5, and $11.5 \mathrm{ka}$ time slices are summarized in Table 2.
Our results are supported by proxy-based temperature reconstructions that indicate a gradual warming in northern extratropical regions $\left(30-90^{\circ} \mathrm{N}\right)$ until $\sim 9.6 \mathrm{ka}$, while tropical temperature remains stable (Marcott et al., 2013). The climate warming in northern high latitudes caused ice sheet retreat (e.g. Dyke, 2004) and may have enhanced $\mathrm{CH}_{4}$ emission by forming new wetlands in permafrost regions (e.g. Gorham et al., 2007; Yu et al., 2013) and accelerating microbial decomposition of organic material (e.g. Christensen et al., 2004; Schuur et al., 2015). Thermokarst lakes created by thawing ice wedges and ground ice in Alaskan and Siberian permafrost has been suggested as a source of $\mathrm{CH}_{4}$ (e.g. Walter et al., 2006, 2007; Brosius et al., 2012). The modelled enhancement of $\mathrm{NH}$ extratropical emission of $\sim 11 \mathrm{Tg} \mathrm{yr}^{-1}$ is similar to the $\mathrm{CH}_{4}$ release of $8.2 \mathrm{Tg} \mathrm{yr}^{-1}$ from thermokarst lake thawing, which is estimated based on present-day observations (Walter Anthony et al., 2014). Since most thermokarst lakes are located in NH high-latitude regions (e.g. Walter et al., 2006; Walter Anthony et al., 2014), this may support the box model results. Our results are consistent with previous findings based on $\mathrm{CH}_{4}$ stable isotope analysis. Fischer et al. (2008) found that increase in boreal source contribution is required to explain the more depleted ${ }^{13} \mathrm{C}-\mathrm{CH}_{4}$ during the Preboreal period than in the Younger Dryas interval. Sowers (2010) extended the $\mathrm{CH}_{4}$ isotopic ratio into the entire Holocene and showed a gradual decrease in $\delta^{13} \mathrm{C}-\mathrm{CH}_{4}$ by $\sim 2 \%$ ofrom 10.5 to $4 \mathrm{ka}$, which was attributed to progressive expansion of $\mathrm{NH}$ high-latitude sources.

\section{Conclusion and summary}

We reconstructed a new high-resolution $\mathrm{CH}_{4}$ record during the early Holocene from Siple Dome ice core, Antarctica, to study millennial $\mathrm{CH}_{4}$ variability and its natural controls under Holocene interglacial condition. The new Siple Dome record agrees well with previous records measured at OSU within analytical uncertainty, showing a mean difference of $0.1 \mathrm{ppb}$. By combining the two data sets, we 
present a SDMA $\mathrm{CH}_{4}$ composite record covering from $\sim 7.7$ to $11.6 \mathrm{ka}$. We observed four millennial-scale $\mathrm{CH}_{4}$ minima having $10-20 \mathrm{ppb}$ of amplitude with 300-400 years' duration. It is found that these $\mathrm{CH}_{4}$ minima were accompanied with Greenland cooling, changes in ITCZ position and reduced Asian and Indian monsoon intensities. The observed evidence suggests that low-latitude hydroclimate changes were closely related to millennial-scale $\mathrm{CH}_{4}$ minima. Further, this study presented the millennial-scale change of IPD, which was calculated from high-resolution discrete data set of NEEM and SDMA, and a continuous record of WAIS Divide. Here we reported that the IPD increased by $\sim 13 \mathrm{ppb}$ from the onset of the Holocene to $\sim 9.5 \mathrm{ka}$ following the temperature rise in $\mathrm{NH}$ extratropical regions. The three-box model demonstrates that $\mathrm{NH}$ extratropical emissions elevated by $\sim 11 \mathrm{Tg} \mathrm{yr}^{-1}$, while tropical emission was reduced by $\sim 9 \mathrm{Tg} \mathrm{yr}^{-1}$, resulting in increased contribution of the $\mathrm{NH}$ extratropical sources by $\sim 5 \%$.

Data availability. The early Holocene Siple Dome $\mathrm{CH}_{4}$ data are available on the NOAA Paleoclimatology database and PANGAEA data repository (https://doi.org/10.1594/PANGAEA.880561; Ahn and Yang, 2017).

Competing interests. The authors declare that they have no conflict of interest.

Special issue statement. This article is part of the special issue "International Partnerships in Ice Core Sciences (IPICS) Second Open Science Conference (CP/TC inter-journal SI)". It is a result of the IPICS 2nd Open Science Conference, Hobart, Australia, 711 March 2016.

Acknowledgements. Financial support was provided by the Basic Science Research Program through the National Research Foundation of Korea (NRF) (NRF-2015R1A2A2A01003888) and Korea Polar Research Institution (KOPRI) research grant (PD12010 and PE15010). This work was also supported by the US National Science Foundation grant PLR 1043518. We appreciate all the efforts of sample cutting and shipping of the Siple Dome ice core by Brian Bencivengo, Richard Nunn, and Geoffrey Hargreaves of National Ice Core Laboratory, Denver, Colorado. We sincerely thank to Yoo-Hyeon Jin, Jinhwa Shin, and Hun-Gyu Lee for their laboratory assistance and helpful discussions. Thanks should go to Heejo Lee for her help in preparing the English manuscript. We are grateful to Mark Twickler and the NICL Science Management Office for providing the Siple Dome ice core samples, the collection of which was supported by the US National Science Foundation. The authors thank the editor and three anonymous reviewers for their patient and careful reading and constructive suggestions that improved this paper.
Edited by: Eric Wolff

Reviewed by: three anonymous referees

\section{References}

Agnihotri, R., Dutta, K., Bhushan, R., and Somayajulu, B. L. K.: Evidence for solar forcing on the Indian monsoon during the last millennium, Earth Planet. Sc. Lett., 198, 521-527, 2002.

Ahn, J. and Yang, J.-W.: Early Holocene methane records from Siple Dome, Antarctica. PANGAEA, https://doi.org/10.1594/PANGAEA.880561, 2017.

Ahn, J., Brook, E. J., and Buizert, C.: Response of atmospheric $\mathrm{CO}_{2}$ to the abrupt cooling event 8200 years ago, Geophys. Res. Lett., 41, 604-609, 2014.

Andreae, M. O. and Merlet, P.: Emission of trace gases and aerosols from biomass burning, Global Biogeochem. Cy., 15, 955-966, 2001.

Berger, A. and Loutre, M. F.: Insolation values for the climate of the last 10 million years, Quaternary Sci. Rev., 10, 297-317, 1991.

Berkelhammer, M., Sinha, A., Stott, L., Cheng, H., Pausata, F., and Yoshimura, K.: An abrupt shift in the Indian Monsoon 4000 years ago, Geophys. Monogr. Ser., 198, 75-87, 2012.

Björck, S., Muscheler, R., Kromer, B., Andresen, C. S., Heinemeier, J., Johnsen, S. J., Conley, D., Koç, N., Spurk, M., and Veski, S.: High-resolution analyses of an early Holocene climate event may imply decreased solar forcing as an important climate trigger, Geology, 29, 1107-1110, 2001.

Blunier, T. and Brook, E. J.: Timing of millennial-scale climate change in Antarctica and Greenland during the last glacial period, Science, 291, 109-112, 2001.

Blunier, T., Chappellaz, J., Schwander, J., Stauffer, B., and Raynaud, D.: Variations in atmospheric methane concentration during the Holocene epoch, Nature, 374, 46-49, 1995.

Bond, G., Showers, W., Cheseby, M., Lotti, R., Almasi, P., deMenocal, P., Priore, P., Cullen, H., Hajdas, I., and Bonani, G.: A pervasive millennial-scale cycle in North Atlantic Holocene and Glacial climates, Science, 278, 1257-1266, 1997.

Bond, G., Kromer, B., Beer, J., Muscheler, R., Evans, M. N., Showers, W., Hoffmann, S., Lotti-Bond, R., Hajdas, I., and Bonani, G.: Persistent solar influence on North Atlantic climate during the Holocene, Science, 294, 2130-2136, 2001.

Broccoli, A. J., Dahl, K. A., and Stouffer, R. J.: Response of the ITCZ to northern hemisphere cooling, Geophys. Res. Lett., 33, L01702, https://doi.org/10.1029/2005GL024546, 2006.

Brook, E. J., Sowers, T., and Orchardo, J.: Rapid variations in atmospheric methane concentration during the past 110,000 years, Science, 273, 1087-1091, 1996.

Brook, E. J., Harder, S., Severinghaus, J. P., Steig, E. J., and Sucher, C. M.: On the origin and timing of rapid changes in atmospheric methane during the last glacial period, Global Biogeochem. Cy., 14, 559-572, 2000.

Brosius, L. S., Walter Anthony, K. M., Grosse, G., Chanton, J. P., Farquharson, L. M., Overduin, P. P., and Meyer, H.: Using the deuterium isotope composition of permafrost meltwater to constrain thermokarst lake contributions to atmospheric $\mathrm{CH}_{4}$ during the last deglaciation, J. Geophys. Res., 117, G01022, https://doi.org/10.1029/2011JG001810, 2012.

Buiron, D., Chappellaz, J., Stenni, B., Frezzotti, M., Baumgartner, M., Capron, E., Landais, A., Lemieux-Dudon, B., Masson- 
Delmotte, V., Montagnat, M., Parrenin, F., and Schilt, A.: TALDICE-1 age scale of the Talos Dome deep ice core, East Antarctica, Clim. Past, 7, 1-16, https://doi.org/10.5194/cp-7-12011, 2011.

Chappellaz, J., Barnola, J. M., Raynaud, D., Korotkevich, Y. S., and Lorius, C.: Ice-core record of atmospheric methane over the past 160,000 years, Nature, 345, 127-131, 1990.

Chappellaz, J., Blunier, T., Raynaud, D., Barnola, J. M., Schwander, J., and Stauffer, B.: Synchronous changes in atmospheric $\mathrm{CH}_{4}$ and Greenland climate between 40 and 8 kyr BP, Nature, 366, 443-445, 1993.

Chappellaz, J., Blunier, T., Kints, S., Dällenbach, A., Barnola, J. M., Schwander, J., Raynaud, D., and Stauffer, B.: Changes in the atmospheric $\mathrm{CH}_{4}$ gradient between Greenland and Antarctica during the Holocene, J. Geophys. Res., 102, 15987-15997, 1997.

Chappellaz, J., Stowasser, C., Blunier, T., Baslev-Clausen, D., Brook, E. J., Dallmayr, R., Faïn, X., Lee, J. E., Mitchell, L. E., Pascual, O., Romanini, D., Rosen, J., and Schüpbach, S.: High-resolution glacial and deglacial record of atmospheric methane by continuous-flow and laser spectrometer analysis along the NEEM ice core, Clim. Past, 9, 2579-2593, https://doi.org/10.5194/cp-9-2579-2013, 2013.

Chiang, J. C. H. and Bitz, C. M.: Influence of high latitude ice core on the marine intertropical convergence zone, Clim. Dynam., 25, 477-496, 2005.

Chiang, J. C. H., Cheng, W., and Bitz, C. M.: Fast teleconnections to the tropical Atlantic sector from Atlantic thermohaline adjustment, Geophys. Res. Lett., 35, L07704, https://doi.org/10.1029/2008GL033292, 2008.

Christensen, T. R., Johansson, T., Jonas Åkerman, H., Mastepanov, M., Malmer, N., Friborg, T., Crill, P., and Svensson, B. H.: Thawing sub-arctic permafrost: effects on vegetation and methane emissions, Geophys. Res. Lett., 31, L04501, https://doi.org/10.1029/2003GL018680, 2004.

Craig, H., Horibe, Y., and Sowers, T.: Gravitational separation of gases and isotopes in polar ice caps, Science, 242, 1675-1678, 1988.

Cruz, F. W., Burns, S. J., Karmann, I., Sharp, W. D., Vuille, M., Cardoso, A. O., Ferrari, J. A., Silva Dias, P. L., and Viana, O.: Insolation-driven changes in atmospheric circulation over the past 116,000 years in subtropical Brazil, Nature, 31, 63-66, https://doi.org/10.1038/nature03365, 2005.

Cvijanovic, I. and Chiang, J. C. H.: Global energy budget changes to high latitude North Atlantic cooling and the tropical ITCZ response, Clim. Dynam., 40, 1435-1452, 2013.

Dai, A. and Wigley, T. M. L.: Global patterns of ENSO-induced precipitation, Geophys. Res. Lett., 27, 1283-1286, 2000.

Deplazes, G., Luckge, A., Peterson, L. C., Timmermann, A., Hamann, Y., Hughen, K. A., Rohl, U., Laj, C., Cane, M. A., Sigman, D. M., and Haug, G. H.: Links between tropical rainfall and North Atlantic climate during the last glacial period, Nat. Geosci., 6, 213-217, 2013.

Dlugokencky, E. J., Myers, R. C., Lang, P. M., Masarie, K. A., Crotwell, A. M., Thoning, K. W., Hall, B. D., Elkins, J. W., and Steele, L. P.: Conversion of NOAA atmospheric dry air $\mathrm{CH}_{4}$ mole fractions to a gravimetrically prepared standard scale, J. Geophys. Res., 110, D18306, https://doi.org/10.1029/2005JD006035, 2005.
Dlugokencky, E. J., Bruhwiler, L., White, J. W. C., Emmons, L. K., Novelli, P. C., Montzka, S. A., Masarie, K. A., Lang, P. M., Crotwell, A. M., Miller, J. B., and Gatti, L. V.: Observational constraints on recent increases in the atmospheric $\mathrm{CH}_{4}$ burden, Geophys. Res. Lett., 36, L18803, https://doi.org/10.1029/2009GL039780, 2009.

Dyke, A. S.: An outline of North American deglaciation with emphasis on central and northern Canada, in: Quaternary Glaciations - Extent and Chronology Part II: North America, Vol. 2, edited by: Ehlers, J. and Gibbard, P. L., Elsevier, Amsterdam, 373-424, 2004.

Dykoski, C. A., Edwards, R. L., Cheng, H., Yuan, D., Cai, Y., Zhang, M., Lin, Y., Qing, J., An, Z., and Revenaugh, J.: A highresolution, absolute-dated Holocene and deglacial Asian monsoon record from Dongge Cave, China, Earth Planet. Sc. Rev., 233, 71-86, 2005.

EPICA Community Members: One-to-one coupling of glacial climate variability in Greenland and Antarctica, Nature, 444, 195198, 2006.

Etiope, G., Lassey, K. R., Klusman, R. W., and Boschi, E.: Reappraisal of the fossil methane budget and related emission from geologic sources, Geophys. Res. Lett., 35, L09307, https://doi.org/10.1029/2008GL033623, 2008.

Ferretti, D., Miller, J. B., White, J. W. C., Etheridge, D. M., Lassey, K. R., Lowe, D. C., MacFarling-Meure, C. M., Dreier, M. F., Trudinger, C. M., van Ommen, T. D., and Langenfelds, R. L.: Unexpected changes to the global methane budget over the past 2000 years, Science, 309, 1714-1717, 2005.

Finkel, R. C. and Nishizumi, K.: Beryllium 10 concentrations in the Greenland Ice Sheet Project 2 ice core from 3-40 ka, J. Geophys. Res., 102, 26699-26706, 1997.

Fischer, H., Behrens, M., Bock, M., Richter, U., Schmitt, J., Loulergue, L., Chappellaz, J., Spahni, R., Blunier, T., Leuenberger, M., and Stocker, T. F.: Changing boreal methane sources and constant biomass burning during the last termination, Nature, 452, 864-867, 2008.

Fleitmann, D., Burns, S. J., Mangini, A., Mudelsee, M., Kramers, J., Villa, I., Neff, U., Al-Subbary, A. A., Buettner, A., Hippler, D., and Matter, A.: Holocene ITCZ and Indian monsoon dynamics recorded in stalagmites from Oman and Yemen (Socotra), Quaternary Sci. Rev., 26, 170-188, 2007.

Fung, I., John, J., Lerner, J., Matthews, E., Prather, M., Steele, L. P., and Fraser, P. J.: Three-dimentional model synthesis of the global methane cycle, J. Geophys. Res., 96, 13033-13065, 1991.

Goldewijk, K. K., Beusen, A., and Janssen, P.: Long-term dynamic modelling of global population and built-up area in a spatially explicit way: HYDE 3.1, Holocene, 20, 565-573, 2010.

Gorham, E., Lehman, C., Dyke, A., Janssens, J., and Dyke, L.: Temporal and spatial aspects of peatland initiation following deglaciation in North America, Quaternary Sci. Rev., 26, 300311, 2007.

Gow, A. J. and Meese, D.: Physical properties, crystalline textures and $c$-axis fabrics of the Siple Dome (Antarctica) ice core, J. Glaciol., 53, 573-584, 2007.

Grachev, A. M., Brook, E. J., and Severinghaus, J. P.: Abrupt changes in atmospheric methane at the MIS 5b-5a transition, Geophys. Res. Lett., 34, L20703, https://doi.org/10.1029/2007GL029799, 2007. 
Grachev, A. M., Brook, E. J., Severinghaus, J. P., and Pisias, N. G.: Relative timing and variability of atmospheric methane and GISP2 oxygen isotopes between 68 and $86 \mathrm{ka}$, Global Biogeochem. Cy., 23, GB2009, https://doi.org/10.1029/2008GB003330, 2009.

Guo, Z., Zhou, X., and Wu, H.: Glacial-interglacial water cycle, global monsoon and atmospheric methane changes, Clim. Dynam., 39, 1073-1092, 2012.

Gupta, A. K., Das, M., and Anderson, D. M.: Solar forcing on the Indian summer monsoon during the Holocene, Geophys. Res. Lett., 32, L17703, https://doi.org/10.1029/2005GL022685, 2005.

Hao, W. M. and Ward, D. E.: Methane production from global biomass burning, J. Geophys. Res., 98, 20657-20661, 1993.

Haug, G. H., Hughen, K. A., Sigman, D. M., Peterson, L. C., and Röhl, U.: Southward migration of the intertropical convergence zone through the Holocene, Science, 293, 1304-1308, 2001.

Hodson, E. L., Poulter, B., Zimmermann, N. E., Prigent, C., and Kaplan, J. O.: The El Niño-Southern Oscillation and wetland methane interannual variability, Geophys. Res. Lett., 38, L08810, https://doi.org/10.1029/2011GL046861, 2011.

Hopcroft, P. O., Valdes, P. J., and Beerling, D. J.: Simulating idealized Dansgaard-Oeschger events and their potential impacts on the global methane cycle, Quat. Sci. Rev., 30, 3258-3268, 2011.

Huber, C., Leuenberger, M., Spahni, R., Fluckiger, J., Schwander, J., Stocker, T. F., Johnsen, S., Landais, A., and Jouzel, J.: Isotope calibrated Greenland temperature record over Marine Isotope Stage 3 and its relation to $\mathrm{CH}_{4}$, Earth Planet. Sc. Lett., 243, 504-519, https://doi.org/10.1016/j.epsl.2006.01.002, 2006.

Hughen, K. A., Overpeck, J. T., Peterson, L. C., and Trumbore, S.: Rapid climate changes in the tropical Atlantic region during the last deglaciation, Nature, 380, 51-54, 1996.

IPCC: Climate Change 2013: The Physical Science Basis, Contribution of Working Group I to the Fifth Assessment Report of the Intergovernmental Panel on Climate Change, edited by: Stocker, T. F., Qin, D., Plattner, G.-K., Tignor, M., Allen, S. K., Boschung, J., Nauels, A., Xia, Y., Bex, V., and Midgley, P. M., Cambridge University Press, Cambridge, UK and New York, NY, USA, 1535 pp., 2013.

Jiang, H., Muscheler, R., Björck, S., Seidenkrantz, M. S., Olsen, J., Sha, L., Sjolte, J., Eriksson, J., Ran, L., Knudsen, K. L., and Knudsen, M. F.: Solar forcing of Holocene summer sea-surface temperatures in the northern North Atlantic, Geology, 43, 203206, https://doi.org/10.1130/G36377.1, 2015.

Joabsson, A. and Christensen, T. R.: Methane emissions from wetlands and their relationship with vascular plants: an Arctic example, Glob. Change Biol., 7, 919-932, 2001.

Kaplan, J. O., Krumhardt, K. M., Ellis, E. C., Ruddiman, W. F., Lemmen, C., and Goldewijk, K. K.: Holocene carbon emissions as a result of anthropogenic land cover change, Holocene, 21, 775-791, 2011.

Kirby, M. E., Lund, S. P., Patterson, W. P., Anderson, M. A., Bird, B. W., Ivanovici, L., Monarrez, P., and Nielsen, S.: A Holocene record of Pacific Decadal Oscillation (PDO)-related hydrologic variability in Southern California (Lake Elsinore, CA), J. Paleolimnol., 44, 819-839, 2010.

Kobashi, T., Severinghaus, J. P., Brook, E. J., Barnola, J.-M., and Grachev, A. M.: Precise timing and characterization of abrupt climate change 8200 years ago from air trapped in polar ice, Quaternary Sci. Rev., 26, 1212-1222, 2007.
Kobashi, T., Severinghaus, J. P., and Barnola, J.-M.: $4 \pm 1.5^{\circ} \mathrm{C}$ abrupt warming $11270 \mathrm{yr}$ ago identified from trapped air in Greenland ice, Earth Planet. Sc. Lett., 268, 397-407, 2008.

Landais, A., Dreyfus, G., Capron, E., Masson-Delmotte, V., Sanchez-Goñi, M. F., Desprat, S., Hoffmann, G., Jouzel, J., Leuenberger, M., and Johnsen, S.: What drives the millennial and orbital variations of $\delta^{18} \mathrm{O}_{\mathrm{atm}}$ ?, Quaternary Sci. Rev., 29, 235246, 2010.

Levine, J. G., Wolff, E. W., Jones, A. E., Sime, L. C., Valdes, P. J., Archibald, A. T., Carver, G. D., Warwick, N. J., and Pyle, J. A.: Reconciling the changes in atmospheric methane sources and sinks between the Last Glacial Maximum and the pre-industrial era, Geophys. Res. Lett., 38, L23804, https://doi.org/10.1029/2011GL049545, 2011.

Levy II, H.: Normal atmosphere: large radical and formaldehyde concentrations predicted, Science, 173, 141-143, 1971.

Loulergue, L., Schilt, A., Sphani, R., Masson-Delmotte, V., Blunier, T., Lemieux, B., Barnola, J. -M., Raynaud, D., Stocker, T. F., and Chappellaz, J.: Orbital and millennial-scale features of atmospheric $\mathrm{CH}_{4}$ over the past 800,000 years, Nature, 453, 383386, 2008.

Lyon, B. and Barnston, A. G.: ENSO and the spatial extent of interannual precipitation extremes in tropical land areas, J. Climate, 18, 5095-5109, 2005.

MacFarling-Meure, C., Etheridge, D., Trudinger, C., Steele, P., Langenfelds, R., van Ommen, T., Smith, A., and Elkins, J.: Law Dome $\mathrm{CO}_{2}, \mathrm{CH}_{4}$ and $\mathrm{N}_{2} \mathrm{O}$ ice core records extended to 2000 years BP, Geophys. Res. Lett., 33, L14810, https://doi.org/10.1029/2006GL026152, 2006.

Marchitto, T. M., Muscheler, R., Ortiz, J. D., Carriquiry, J. D., and van Geen, A.: Dynamical response of the tropical Pacific Ocean to solar forcing during the early Holocene, Science, 330, 13781381, 2010.

Marcott, S. A., Shakun, J. D., Clark, P. U., and Mix, A. C.: A reconstruction of regional and global temperature for the past 11300 years, Science, 339, 1198-1201, 2013.

Mischler, J. A., Sowers, T. A., Alley, R. B., Battle, M., McConnell, J. R., Mitchell, L., Popp, T., Sofen, E., and Spencer, M. K.: Carbon and hydrogen isotopic composition of methane over the last 1000 years, Global Biogeochem. Cy., 23, GB4024, https://doi.org/10.1029/2009GB003460, 2009.

Mitchell, L. E., Brook, E. J., Sowers, T., McConnell, J. R., and Taylor, K.: Multidecadal variability of atmospheric methane, 1000-1800 C.E., J. Geophys. Res., 116, G02007, https://doi.org/10.1029/2010JG001441, 2011.

Mitchell, L. E., Brook, E. J., Lee, J. E., Buizert, C., and Sowers, T.: Constraints on the Late Holocene anthropogenic contribution to the atmospheric methane budget, Science, 342, 964-966, 2013.

Moy, C. M., Seltzer, G. O., Rodbell, D. T., and Anderson, D. M.: Variability of El Niño/Southern Oscillation activity at millennial timescales during the Holocene epoch, Nature, 420, 162-165, 2002.

Neff, U., Burns, S. J., Mangini, A., Mudelsee, M., Fleitmann, D., and Matter, A.: Strong coherence between solar variability and the monsoon in Oman between 9 and $6 \mathrm{kyr}$ ago, Nature, 411, 290-293, 2001.

Prather, M. J., Holmes, C. D., and Hsu, J.: Reactive greenhouse gas scenarios: Systematic exploration of uncertainties and the 
role of atmospheric chemistry, Geophys. Res. Lett., 39, L0980, https://doi.org/10.1029/2012GL051440, 2012.

Peterson, L. C., Haug, G. H., Hughen, K. A., and Rohl, U.: Rapid changes in the hydrologic cycle of the Tropical Atalntic during the Last Glacial, Science, 290, 1947-1951, https://doi.org/10.1126/science.290.5498.1947, 2000.

Rasmussen, S. O., Andersen, K. K., Svensson, A. M., Steffensen, J. P., Vinther, B. M., Clausen, H. B., Siggaard-Andersen, M.L., Johnsen, S. J., Larsen, L. B., Dahl-Jensen, D., Bigler, M., Rothlisberger, R., Fischer, H., Goto-Azuma, K., Hansson, M. E., and Ruth, U.: A new Greenland ice core chronology for the last glacial termination, J. Geophys. Res., 111, D06102, https://doi.org/10.1029/2005JD006079, 2006.

Rasmussen, S. O., Abbott, P. M., Blunier, T., Bourne, A. J., Brook, E., Buchardt, S. L., Buizert, C., Chappellaz, J., Clausen, H. B., Cook, E., Dahl-Jensen, D., Davies, S. M., Guillevic, M., Kipfstuhl, S., Laepple, T., Seierstad, I. K., Severinghaus, J. P., Steffensen, J. P., Stowasser, C., Svensson, A., Vallelonga, P., Vinther, B. M., Wilhelms, F., and Winstrup, M.: A first chronology for the North Greenland Eemian Ice Drilling (NEEM) ice core, Clim. Past, 9, 2713-2730, https://doi.org/10.5194/cp-92713-2013, 2013.

Rhee, T. S., Kettle, A. J., and Andreae, M. O.: Methane and nitrous oxide emissions from the ocean: A reassessment using basin-wide observations in the Atlantic, J. Geophys. Res., 114, D12304, https://doi.org/10.1029/2008JD011662, 2009.

Rhodes, R. H., Brook, E. J., Chiang, J. C. H., Blunier, T., Maselli, O. J., McConnell, J. R., Romanini, D., and Severinghaus, J. P.: Enhanced tropical methane production in response to iceberg discharge in the North Atlantic, Science, 348, 1016-1019, 2015.

Ruddiman, W. F., Kutzbach, J. E., and Vavrus, S. J.: Can natural or anthropogenic explanations of late-Holocene $\mathrm{CO}_{2}$ and $\mathrm{CH}_{4}$ increases be falsified?, Holocene, 21, 865-879, 2011.

Sanderson, M. G.: Biomass of termites and their emissions of methane and carbon dioxide: A global database, Global Biogeochem. Cy., 10, 543-558, 1996.

Sapart, C. J., Monteil, G., Prokopiou, M., van de Wal, R. S. W., Kaplan, J. O., Sperlich, P., Krumhardt, K. M., van der Veen, C., Houweling, S., Krol, M. C., Blunier, T., Sowers, T., Martinerie, P., Witrant, E., Dahl-Jensen, D., and Röckmann, T.: Natural and anthropogenic variations in methane sources during the past two millennia, Nature, 490, 85-88, 2012.

Schuur, E. A. G., McGuire, A. D., Schadel, C., Grosse, G., Harden, J. W., Hayes, D. J., Hugelius, G., Koven, C. D., Kuhry, P., Lawrence, D. M., Natali, S. M., Olefeldt, D., Romanovsky, V. E., Schaefer, K., Turetsky, M. R., Treat, C. C., and Vonk, J. E.: Climate change and the permafrost carbon feedback, Nature, 520, $171-179,2015$

Schwander, J.: The transformation of snow to ice and the occlusion of gases, in: The environmental record in glaciers and ice sheets, edited by: Oeschger, H. and Langway, C. C., Physical, Chemical, and Earth Sciences Research reports, John Wiley and Sons Ltd., New York, 53-67, 1989.

Schulz, M. and Mudelsee, M.: REDFIT: estimating red-noise spectra directly from unevenly spaced paleoclimatic time series, Comput. Geosci., 28, 421-426, 2002.

Severinghaus, J. P., Beaudette, R., Headly, M. A., Taylor, K., and Brook, E. J.: Oxygen-18 of $\mathrm{O}_{2}$ records the impact of abrupt cli- mate change on the terrestrial biosphere, Science, 324, 14311434, 2009.

Sowers, T.: Atmospheric methane isotope records covering the Holocene period, Quaternary Sci. Rev., 29, 213-221, 2010.

Spahni, R., Schwander, J., Flückiger, J., Stauffer, B., Chappellaz, J., and Raynaud, D.: The attenuation of fast atmospheric $\mathrm{CH}_{4}$ variations recorded in polar ice cores, Geophys. Res. Lett., 30, 1571, https://doi.org/10.1029/2003GL017093, 2003.

Spahni, R., Chappellaz, J., Stocker, T. F., Loulergue, L., Hausammann, G., Kawamura, K., Flückiger, J., Schwander, J., Raynaud, D., Masson-Delmotte, V., and Jouzel, J.: Atmospheric methane and nitrous oxide of late Pleistocene from Antarctic ice cores, Science, 310, 1317-1321, 2005.

Sperlich, P., Schaefer, H., Mikaloff Fletcher, S. E., Guillevic, M., Lassey, K., Sapart, C. J., Röckmann, T., and Blunier, T.: Carbon isotope ratios suggest no additional methane from boreal wetlands during the rapid Greenland Interstadial 21.2, Global Biogeochem. Cy., 29, 1962-1976, 2015.

Strikis, N. M., Cruz, F. W., Cheng, H., Karmann, I., Edwards, R. L., Vuille, M., Wang, X., de Paula, M. S., Novello, V. F., and Auler, A. S.: Abrupt variations in South American monsoon rainfall during the Holocene based on a speleothem record from centraleastern Brazil, Geology, 39, 1075-1078, 2011.

Stuiver, M. and Grootes, P. M.: GISP2 oxygen isotope ratios, Quaternary Res., 53, 277-284, https://doi.org/10.1006/qres.2000.2127, 2000.

Taylor, K. C., Alley, R. B., Meese, D. A., Spencer, M. K., Brook, E. J., Dunbar, N. W., Finkel, R. C., Gow, A. J., Kurbatov, A. V., Lamorey, G. W., Mayewski, P. A., Meyerson, E. A., Nishiizumi, K., and Zielinski, G. A.: Dating the Siple Dome (Antarctica) ice core by manual and computer interpretation of annual layering, J. Glaciol., 50, 453-461, 2004.

Teller, J. T. and Leverington, D. W.: Glacial lake Agassiz: a $5000 \mathrm{yr}$ history of change and its relationship to the $\delta^{18} \mathrm{O}$ record of Greenland, Geol. Soc. Am. Bull., 116, 729-742, 2004.

Tzedakis, P. C., Pälike, H., Roucoux, K. H., and de Abreu, L.: Atmospheric methane, southern European vegetation and low-mid latitude links on orbital and millennial timescales, Earth Planet. Sc. Lett., 277, 307-317, 2009.

Valdes, P. J., Beerling, D. J., and Johnson, C. E.: The ice age methane budget, Geophys. Res. Lett., 32, L02704, https://doi.org/10.1029/2004GL021004, 2005.

WAIS Divide Project Members: Precise interpolar phasing of abrupt climate change during the last ice age, Nature, 520, 661-665, 2015.

Walter, K. M., Zimov, S. A., Chanton, J. P., Verbyla, D., and Chapin III, F. S.: Methane bubbling from Siberian thaw lakes as a positive feedback to climate warming, Nature, 443, 71-75, 2006.

Walter, K. M., Edwards, M. E., Grosse, G., Zimov, S. A., and Chapin III, F. S.: Thermokarst lakes as a source of atmospheric $\mathrm{CH}_{4}$ during the last deglaciation, Science, 318, 633-636, 2007.

Walter Anthony, K. M., Zimov, S. A., Grosse, G., Jones, M. C., Anthony, P. M., Chapin III, F. S., Finlay, J. C., Mack, M. C., Davydov, S., Frenzel, P., and Frolking, S.: A shift of thermokarst lakes from carbon sources to sinks during the Holocene epoch, Nature, 511, 452-456, 2014.

Wang, S., Huang, J., He, Y., and Guan, Y.: Combined effects of the Pacific Decadal Oscillation and El Niño-Southern Os- 
cillation on global land dry-wet changes, Sci. Rep., 4, 6651, https://doi.org/10.1038/srep06651, 2014.

Wang, Y., Cheng, H., Edwards, R. L., He, Y., Kong, X., An, Z., Wu, J., Kelly, M. J., Dykoski, C. A., and Li, X.: The Holocene Asian monsoon: links to solar changes and north Atlantic climate, Science, 308, 854-857, 2005.

Weber, S. L., Drury, A. J., Toonen, W. H. J., and van Weele, M.: Wetland methane emissions during the Last Glacial Maximum estimated from PMIP2 simulations: Climate, vegetation, and geographic controls, J. Geophys. Res., 115, D06111, https://doi.org/10.1029/2009JD012110, 2010.

Weldeab, S., Lea, D. W., Schneider, R. R., and Andersen, N.: 155,000 years of West African monsoon and ocean thermal evolution, Science, 316, 1303-1307, 2007.
Yang, J.-W., Ahn, J., and Brook, E. J.: Accuracy and precision of a wet extraction technique for measurements of methane concentration and total air content for frozen ice samples, in preparation, 2017.

Yu, Z., Loisel, J., Turetsky, M. R., Cai, S., Zhao, Y., Frolking, S., MacDonald, G. M., and Bubier, J. L.: Evidence for elevated emissions from high-latitude wetlands contributing to high atmospheric $\mathrm{CH}_{4}$ concentration in the early Holocene, Global Biogeochem. Cy., 27, 1-10, 2013.

Zürcher, S., Spahni, R., Joos, F., Steinacher, M., and Fischer, H.: Impact of an abrupt cooling event on interglacial methane emissions in northern peatlands, Biogeosciences, 10, 1963-1981, https://doi.org/10.5194/bg-10-1963-2013, 2013. 